\title{
Using synoptic type analysis to understand New Zealand climate during the Mid-Holocene
}

\author{
D. Ackerley ${ }^{1, *}$, A. Lorrey ${ }^{2}$, J. A. Renwick ${ }^{1}$, S. J. Phipps ${ }^{3}$, S. Wagner ${ }^{4}$, S. Dean ${ }^{1}$, J. Singarayer ${ }^{5}$, P. Valdes ${ }^{5}$, \\ A. Abe-Ouchi ${ }^{6}$, R. Ohgaito ${ }^{7}$, and J. M. Jones ${ }^{8}$ \\ ${ }^{1}$ National Institute of Water and Atmospheric Research Ltd, Private Bag 14901, Kilbirnie, Wellington, New Zealand \\ ${ }^{2}$ National Institute of Water and Atmospheric Research Ltd, Private Bag 99940, Newmarket, Auckland 1149, New Zealand \\ ${ }^{3}$ Climate Change Research Centre, University of New South Wales, Sydney, Australia \\ ${ }^{4}$ GKSS Research Center, Institute for Coastal Research, Paleoclimate Group, Max Planck Strasse 1, \\ 21502 Geesthacht, Germany \\ ${ }^{5}$ Bristol Research Initiative for the Dynamic Global Environment, Geographical Sciences, University of Bristol, Bristol, \\ BS8 1SS, UK \\ ${ }^{6}$ Center for Climate System Research, The University of Tokyo, 5-1-5 Kashiwanoha, Kashiwa, 277-8568, Japan \\ ${ }^{7}$ Japan Agency for Marine-Earth Science and Technology, Showa-machi 3173-25, Kanazawa-ward Yokohama, \\ 236-0001, Japan \\ ${ }^{8}$ Department of Geography, University of Sheffield, UK \\ * currently at: Monash Weather and Climate, Monash University, Clayton, Victoria, 3800, Australia
}

Received: 23 March 2011 - Published in Clim. Past Discuss.: 19 April 2011

Revised: 29 August 2011 - Accepted: 7 October 2011 - Published: 9 November 2011

\begin{abstract}
Diagnosing the climate of New Zealand from low-resolution General Circulation Models (GCMs) is notoriously difficult due to the interaction of the complex topography and the Southern Hemisphere (SH) mid-latitude westerly winds. Therefore, methods of downscaling synoptic scale model data for New Zealand are useful to help understand past climate. New Zealand also has a wealth of palaeoclimate-proxy data to which the downscaled model output can be compared, and to provide a qualitative method of assessing the capability of GCMs to represent, in this case, the climate $6000 \mathrm{yr}$ ago in the Mid-Holocene.

In this paper, a synoptic weather and climate regime classification system using Empirical Orthogonal Function (EOF) analysis of GCM and reanalysis data was used. The climate regimes are associated with surface air temperature and precipitation anomalies over New Zealand. From the analysis in this study, we find at $6000 \mathrm{BP}$ that increased trough activity in summer and autumn led to increased precipitation, with an increased north-south pressure gradient ("zonal events") in winter and spring leading to drier conditions. Opposing effects of increased (decreased) temperature are also seen in
\end{abstract}

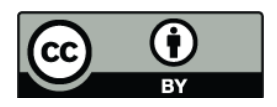

Correspondence to: D. Ackerley (duncan.ackerley@monash.edu) spring (autumn) in the South Island, which are associated with the increased zonal (trough) events; however, the circulation induced changes in temperature are likely to have been of secondary importance to the insolation induced changes. Evidence from the palaeoclimate-proxy data suggests that the Mid-Holocene was characterized by increased westerly wind events in New Zealand, which agrees with the preference for trough and zonal regimes in the models.

\section{Introduction}

The generation of palaeoclimate-proxy data reconstructions has allowed us to understand how the climate of the past has differed from the present day. By comparing the proxy reconstructions with General Circulation Model (GCM) data, we can evaluate whether the modelled climate is consistent with the palaeoclimate proxy reconstructions. Proxy-model intercomparison establishes the ability of climate models to simulate past climatic change, which is an essential step in evaluating the GCMs used to simulate future climate. However, comparing model data with proxy data is difficult, particularly in New Zealand, where the low resolution of GCMs cannot represent the fine-scale topographical features

Published by Copernicus Publications on behalf of the European Geosciences Union. 
of the land, which are important in governing the regional climate characteristics such as temperature and precipitation (see Mullan, 1998; Salinger, 1980a,b; Salinger and Mullan, 1999). Therefore, a method of bridging the scale gap from coarse resolution GCM to local proxy resolution data, either through downscaling or upscaling, must be employed.

A novel method for "upscaling" regional climate information from proxy reconstructions has been undertaken by Lorrey et al. (2007, 2008). Lorrey et al. (2007) used multiproxy data to produce regional precipitation anomaly patterns and then related them to the larger scale atmospheric circulation patterns established by Kidson (2000) that are seen on weather time scales. Lorrey et al. (2007) argued there was a self-similar nature to the patterns observed on weather time scales that could be expressed on seasonal and longer timescales. It was hypothesised that the net effect of increased frequency of specific synoptic types would register in proxy archives and reveal the predominant direction of past atmospheric circulation anomalies.

Kidson (2000) used cluster and Empirical Orthogonal Function (EOF) analyses on 12-hourly geopotential height data at $1000 \mathrm{hPa}$ from the NCEP/NCAR reanalysis archive from January 1958 to June 1997 (for more information on the NCEP/NCAR reanalysis, see Kalnay et al., 1996) to produce a set of twelve synoptic "weather types" that can be seen in Fig. 1. The work by Kidson (2000) built upon previous studies (see Kidson, 1994a,b; Sturman et al., 1984) that used different sets of synoptic types to those given in Fig. 1. The twelve synoptic types in Fig. 1 come from the study of Kidson (2000) and are the set considered in this study.

The twelve Kidson synoptic types are shown in Fig. 1 as average patterns of $1000 \mathrm{~h} \mathrm{~Pa}$ geopotential height (analogous to mean sea-level pressure) from NCEP reanalysis data. Names for the types are indicated in top right of each panel, where T stands for Trough, SW for Southwesterly, TNW for Trough-Northwesterly, TSW for Trough-Southwesterly, $\mathrm{H}$ for High, HNW for High to the Northwest, W for Westerly, HSE for High to the Southeast, HE for High to the East, NE for Northeasterly, HW for High to the West, and R for Ridge. These individual synoptic types can then be grouped into regimes, which are based upon a further cluster analysis (see Kidson, 1997, 2000, for more details)

The three regimes are indicated at left of Fig. 1: the top row is the trough regime, the first three in the middle row are the zonal regime, and the rest are the blocking regime (see Kidson, 2000, for more details). According to Kidson (2000), trough regimes are associated with above-normal precipitation throughout New Zealand and below-normal temperatures in the annual mean. The zonal regime (for the annual mean) is associated with near-normal-to-cooler temperatures in the North Island and near-normal-to-warmer conditions in the South Island, with dry conditions in most places of both islands apart from the far south and west of the South Island. Finally, the blocking regime is associated with generally warmer temperatures throughout New Zealand, with reduced precipitation in the southwestern North and South Islands and increased precipitation in the northern and eastern North Island in the annual mean.

The Kidson (2000) synoptic types and regimes were originally defined on a daily basis. However, changes in the synoptic type frequency are associated with distinct regimes that generate regionally disparate precipitation and temperature anomalies in New Zealand climate over months, seasons, and longer periods (demonstrated by Lorrey et al., 2007). The dominance of a particular circulation regime on seasonal, annual or decadal time-scales may therefore be detectable in the instrumental and palaeoclimate-proxy, precipitation and temperature records. Lorrey et al. (2007) demonstrated proof of concept in indicating that such changes in regional climate regime predominance occurred (on low-frequency time scales) as a result of the 1976/1977 Inter-decadal Pacific Oscillation (IPO) phase change. Lorrey et al. (2007) then examined three periods during the last (approximately) $2000 \mathrm{yr}$ to infer which basic regional climate regime, and synoptic circulation pattern, may have been dominant on the basis of palaeo-precipitation and temperature records. Such climate regimes and circulation patterns can also be identified from the coarse resolution GCM simulations, which allow a qualitative but direct comparison between the models and multi-proxy data assemblages that underpin regional climate regime classification (Lorrey et al., 2007, 2008).

Many global modelling groups have produced valuable GCM simulations for representations of the Mid-Holocene (6000 yr before present, ybp) and the Last Glacial Maximum (21 $000 \mathrm{ybp})$, which are stored as part of the Palaeoclimate Modelling Intercomparison Project (PMIP, see Joussaume and Taylor, 2000). Despite the large archive of model data (see Braconnot et al., 2007, for an overview of the PMIP2 model results), there have been relatively few studies of the Southern Hemisphere (SH) climate (for examples see Ackerley and Renwick, 2010; Rojas et al., 2009; Rojas and Moreno, 2011) from the PMIP2 data. There have, however, been some studies of the SH westerlies from other model simulations (Wagner et al., 2007; Wardle, 2003). Given the issues in representing $\mathrm{SH}$ mid-latitude circulation in GCMs (see Randall et al., 2007), and the sparsity of SH observational data, methods of assessing GCM simulations in comparison to instrumental or proxy records are very important. The use of different climate models is essential for investigations on natural climate variability because of the differences in mean climate and the model-inherent biases. To reduce the uncertainty concerning model specific features, we use four different models, three of which have been used by PMIP. The model output is used to statistically downscale the large-scale atmospheric circulation to the local climate in New Zealand. This should help to discriminate between robust, climatically induced climate changes (due to changes in external forcing) and model-specific features, which are potentially unrelated to the combination of naturally forced internal and external climate variability. 

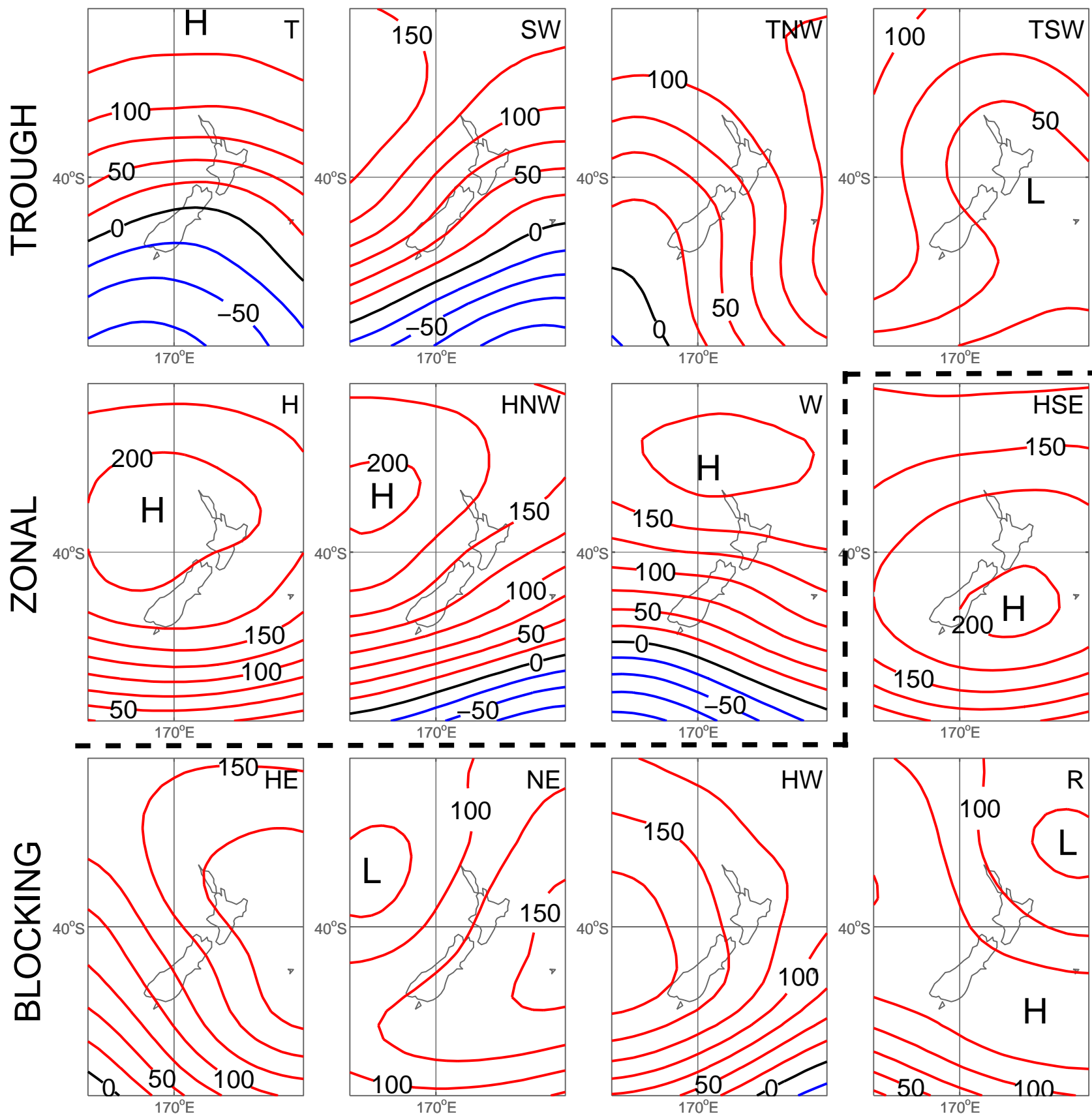

Fig. 1. The twelve Kidson weather types, shown as average patterns of $1000 \mathrm{hPa}$ geopotential height (analogous to mean sea-level pressure). Names for the types are indicated in the top right of each panel (see text for details). The three regimes are indicated at the left: the top row is the trough regime, the first three in the second row are the zonal regime, and the rest form the blocking regime. See Kidson (2000) for further details.

The aims of this study, therefore, are to provide a first step for assessing $\mathrm{SH}$ circulation patterns as represented by a set of GCMs that cover the Mid-Holocene, using the synoptic climate regime classification method of Kidson (2000) and then comparing those results to palaeoclimate proxy data within the New Zealand sector to see if the models and prox- ies agree. Ackerley and Renwick (2010) have already shown that the seasonal SH mid-latitude circulation is sensitive to differences in the Earth's orbital paramaters during the MidHolocene, which cause changes in seasonal insolation (see Fig. 2). We would therefore expect the frequency of synoptic types shown in Fig. 1 to change during the Mid-Holocene. 


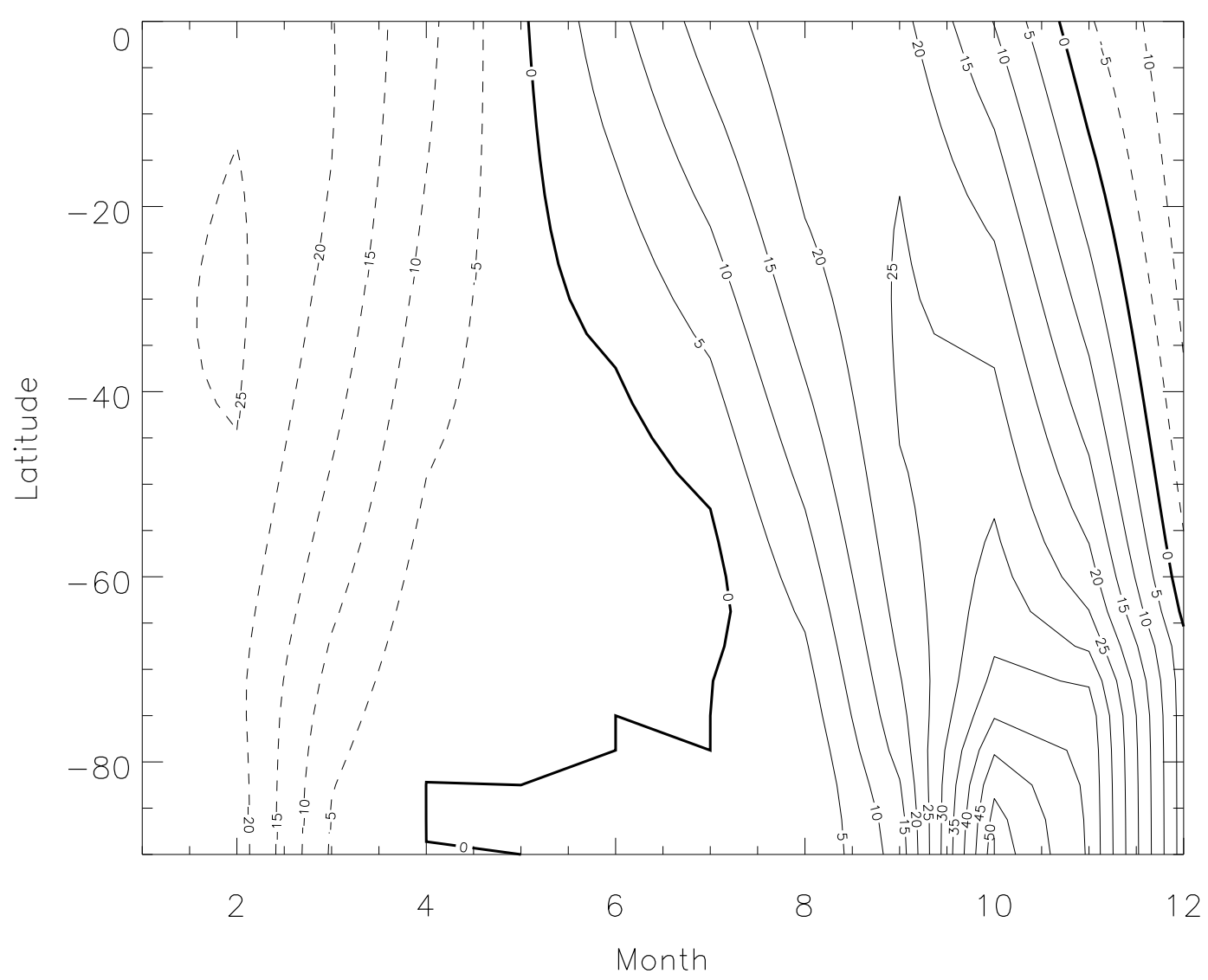

Fig. 2. The calculated difference in zonal, seasonal mean insolation for the Mid-Holocene relative to the pre-industrial control (W $\mathrm{m}^{-2}$ ) from Ackerley and Renwick (2010). Positive (negative) values are indicated by the solid (dashed) lines. The zero line is the thick black line.

To test this hypothesis we will assess if the synoptic type frequency in the New Zealand sector has changed and relate these changes to seasonal climate regimes, from which regional precipitation and temperature patterns can be inferred. A further test of the synoptic type frequency changes during the Mid-Holocene, as determined by the model ensemble, is to then compare the results to past conditions established by palaeoclimate regime reconstructions for the same time period.

A description of the models used in this analysis and the data provided can be found in Sect. 2. An analysis of the seasonal differences in the climate regimes can be found in Sect. 3 along with their relation to the wider SH circulation. A discussion of the implications for New Zealand temperature and precipitation from the results in Sect. 3 will be given in Sect. 4 and the main conclusions will be given in Sect. 5 .

\section{Models, data and method}

\subsection{Model experiments and model data}

This study makes use of data from four fully coupled oceanatmosphere general circulation models, which are described in Table 1. Two simulations were undertaken with each model: one with orbital parameters for the Earth (eccentricity, obliquity and angular precession) set to the present day values, and another for $6000 \mathrm{yr}$ before present (ybp) in the Mid-Holocene (see Braconnot et al., 2007, for more details on the values of the orbital parameters). The different parameters influence the amount of insolation at the top-of-theatmosphere and subsequently the solar energy absorbed at the surface. The difference in seasonal insolation at the topof-the-atmosphere at $6000 \mathrm{ybp}$ relative to the present day (for the Southern Hemisphere) can be seen in Fig. 2 and is representative for each of the models given in Table 1. The solar constant is set to $1365 \mathrm{~W} \mathrm{~m}^{-2}$ in each of the models; however, there are some differences in greenhouse gas and data availability which are discussed below: 
1. CSIRO Mk3L: $50 \mathrm{yr}$ simulations (Mid-Holocene - MH, and Pre-Industrial - PI) of the model with sea level pressure (SLP) data sampled at 00:00 UTC each model day. Monthly mean surface air temperatures at $2 \mathrm{~m}$ were also provided. Carbon-dioxide $\left(\mathrm{CO}_{2}\right)$ concentrations were set to $280 \mathrm{ppm}$ with no other greenhouse gases (such as methane, $\mathrm{CH}_{4}$, and nitrous-oxide, $\mathrm{N}_{2} \mathrm{O}$ ) explicitly represented in the model simulation.

2. ECHO-G: these data were taken from the simulations undertaken in Wagner et al. (2007); $50 \mathrm{yr}$ of daily mean SLP and surface air temperature at $2 \mathrm{~m}$ were used. $\mathrm{CO}_{2}, \mathrm{~N}_{2} \mathrm{O}$ and $\mathrm{CH}_{4}$ were set to $280 \mathrm{ppm}, 265 \mathrm{ppb}$ and $700 \mathrm{ppb}$, respectively, in both simulations (MH and PI). The resolution of the ocean model is increased in the tropics (see Table 1) to represent the effects of the El Nino Southern Oscillation better.

3. HadCM3_UB: data were taken from $100 \mathrm{yr}$ simulations (MH and PI) used in the PMIP2 ensemble by Braconnot et al. (2007). $\mathrm{CO}_{2}$ and $\mathrm{N}_{2} \mathrm{O}$ were set to $280 \mathrm{ppm}$ and $270 \mathrm{ppb}$, respectively, in both simulations (preindustrial and $6000 \mathrm{ybp}$ ). $\mathrm{CH}_{4}$ was set to $760 \mathrm{ppb}$ in the pre-industrial control simulation and $650 \mathrm{ppb}$ for $6000 \mathrm{ybp}$. More details of this simulation can be found in Singarayer and Valdes (2010).

4. MIROC: data were taken from $100 \mathrm{yr}$ simulations (MH and PI) used in the PMIP2 ensemble by Braconnot et al. (2007). $\mathrm{CO}_{2}$ and $\mathrm{N}_{2} \mathrm{O}$ were set to $280 \mathrm{ppm}$ and $270 \mathrm{ppb}$, respectively, in both simulations (pre-industrial and $6000 \mathrm{ybp}$ ). $\mathrm{CH}_{4}$ was set to $760 \mathrm{ppb}$ in the pre-industrial control simulation and $650 \mathrm{ppb}$ for $6000 \mathrm{ybp}$. More details of this simulation can be found in Ohgaito and AbeOuchi (2007).

The CSIRO Mk3L, HadCM3_UB and MIROC simulations were "time slice" experiements, which follow the PMIP2 experimental design, whereas the ECHO-G data were taken from a non-PMIP2 transient simulation. While these differences are an important consideration, they are unlikely to affect the results of the analysis presented (see Renssen et al., 2006).

\subsection{EOF procedure for synotic classification}

The EOF analysis used by Kidson (2000) requires $1000 \mathrm{hPa}$ geopotential height data, and while SLP is analogous to $1000 \mathrm{hPa}$ geopotential height, it is not the same. The modeloutput SLP data were converted to equivalent $1000 \mathrm{hPa}$ height using the monthly mean surface air temperature provided by each modelling group in the hypsometric equation (see http://amsglossary.allenpress.com/glossary/search? id=hypsometric-equation1). The classification procedure documented in Kidson $(1997,2000)$ is then applied on the converted SLP data, which assigns the "closest" synoptic type from Fig. 1 to each day of the data sets. The "closest" synoptic type is calculated as the minimum Euclidian distance to the mean height field associated with each of the synoptic types. The distance is calculated in terms of the first five principal components of the $1000 \mathrm{hPa}$ height field (see Kidson, 1997, 2000, for more details).

The output from the synoptic classification procedure is considered on a seasonal basis where the austral seasons are defined to be December-January-February (DJF, summer), March-April-May (MAM, autumn), June-July-August (JJA, winter) and September-October-November (SON, spring). The totals in each season for each year can then be summed to give the total frequency of occurrence of synoptic types in each regime during the Mid-Holocene and pre-industrial simulations (see Table 2). Changes in regional New Zealand climate therefore can be inferred from systematic changes in the frequency of occurrence of the individual synoptic types on weather time scales (based on the relationships between the Kidson, 2000, types and modern observations). Application of the same anomalies to the Mid-Holocene follows uniformitarian principles that suggest similar changes would result in climate regime shifts over longer time periods. Ackerley and Renwick (2010) found that the strongest changes in the SH circulation occurred in SON and MAM, and were associated with the sea-surface temperature response to the changes in insolation shown in Fig. 2. Therefore, we expect the largest changes in the synoptic regimes to occur in SON and MAM but all seasons will be considered.

\section{Results}

The seasonal frequency of occurrence and the difference between the Mid-Holocene (MH) and pre-industrial (PI) control runs for each of the synoptic regimes given in Sect. 1 can be seen in Table 2. The differences in the frequency of occurrence were subjected to a z-test for two proportions. Changes that are statistically significant $(p \leq 0.05)$ have an asterisk. For comparison with the results in Table 2, the difference in sea level pressure (SLP) for the MH relative to the PI for each of the seasons can be seen in Figs. 3-6. These changes in SLP were subjected to a t-test for equal means, and statistically significant changes in SLP $(p \leq 0.05)$ for the MH relative to the PI are shaded grey.

The seasonal frequencies of occurrence for the NCEP reanalysis data (over the period 1972-2009) are given in Table 2 . The models do reasonably well at capturing the seasonal variation in the regime frequencies as an ensemble mean. However, there are obvious differences between the individual models and the NCEP data, and generally the models do better in MAM and SON than in DJF and JJA. The cause of some of the differences may be due to the models representing a pre-industrial climate (circa 1750), whereas NCEP data are for present day. Therefore, the discussion will focus on the coherent changes in the regimes that are 
(a) CSIRO

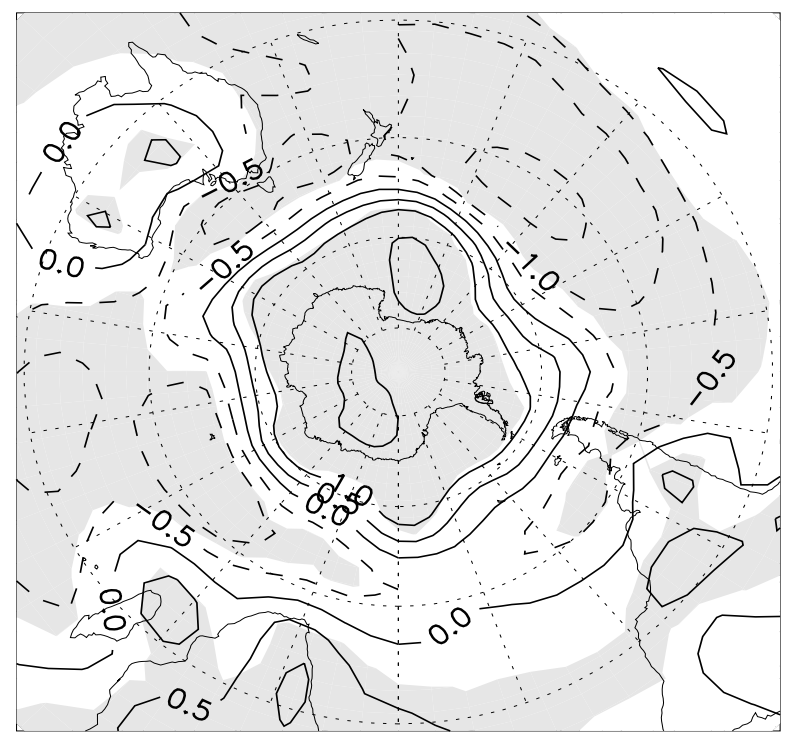

(c) HadCM3_UB

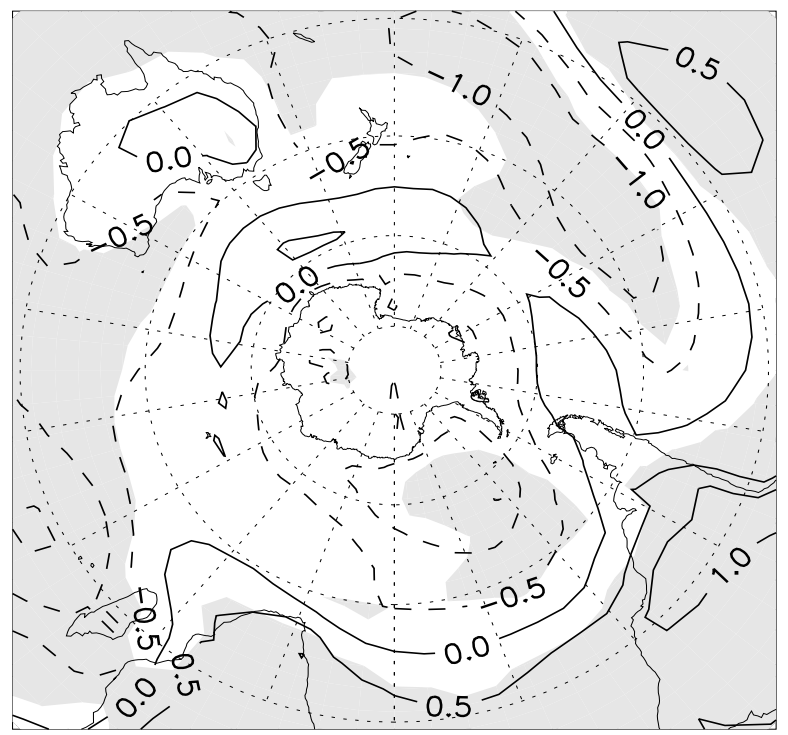

(b) $\mathrm{ECHO}-\mathrm{G}$

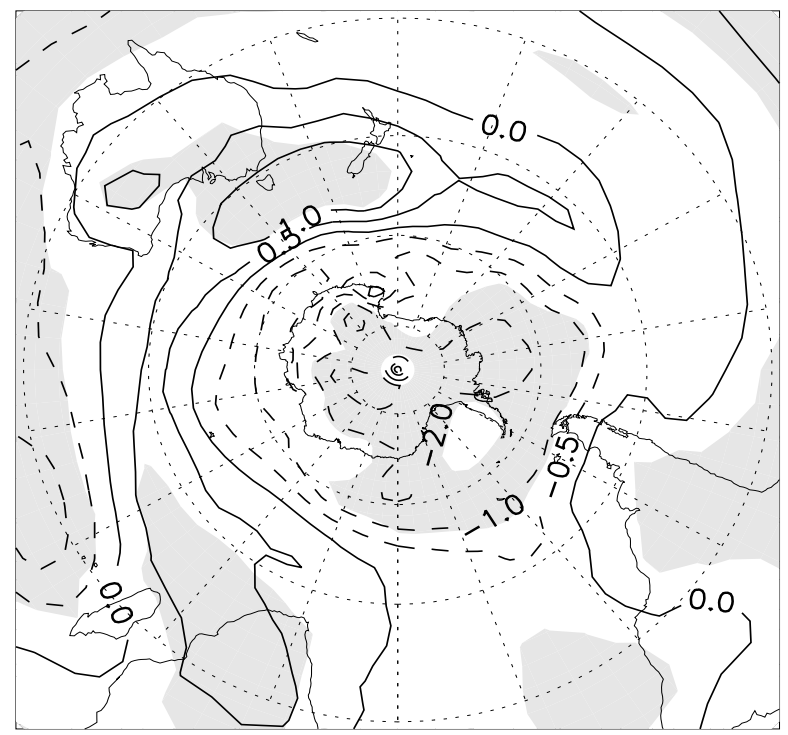

(d) MIROC

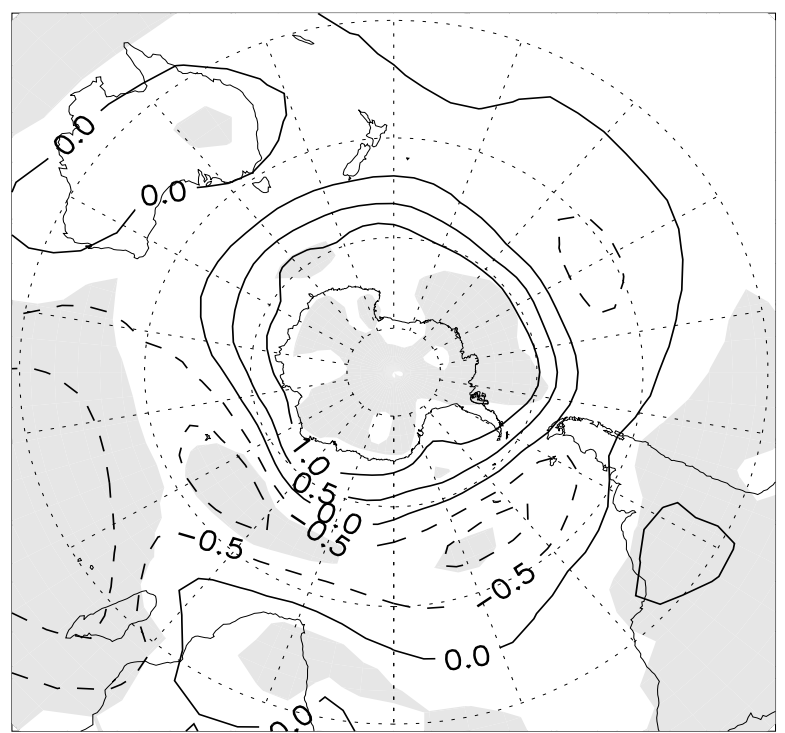

Fig. 3. The difference in DJF mean sea level pressure (hPa) for the Mid-Holocene relative to the pre-industrial control run for (a) CSIRO Mk3L, (b) ECHO-G, (c) HadCM3_UB, and (d) MIROC. Solid (dashed) contours indicate positive (negative) changes in pressure. Statistically significant changes in SLP $(p \leq 0.05)$ are shaded grey. 
Table 1. Characteristics of the models used in this study.

\begin{tabular}{|c|c|c|c|c|}
\hline $\begin{array}{l}\text { Model Name } \\
\text { in the text }\end{array}$ & $\begin{array}{r}\text { Atmosphere } \\
\text { resolution } \\
\text { [lon x lat] (levels) }\end{array}$ & $\begin{array}{r}\text { Ocean } \\
\text { resolution } \\
{[\text { lon x lat] (levels) }}\end{array}$ & $\begin{array}{c}\text { Number of } \\
\text { available years } \\
\text { of data }\end{array}$ & $\begin{array}{l}\text { Model } \\
\text { reference }\end{array}$ \\
\hline CSIRO Mk3L & {$\left[5.6^{\circ} \times 3.2^{\circ}\right](18)$} & {$\left[2.8^{\circ} \times 1.6^{\circ}\right](21)$} & 50 & Phipps et al. (2011) \\
\hline ECHO-G & {$\left[3.75^{\circ} \times 3.75^{\circ}\right](19)$} & $\begin{array}{r}{\left[2.8^{\circ} \times 2.8^{\circ}\right](20)} \\
{\left[0.5^{\circ} \times 0.5^{\circ}, \text { in the tropics }\right]}\end{array}$ & 50 & $\begin{array}{l}\text { Legutke and Voss (1999); Roeckner et al. (1996); } \\
\text { Wolff et al. (1997) }\end{array}$ \\
\hline HadCM3_UB & {$\left[3.75^{\circ} \times 2.5^{\circ}\right](19)$} & {$\left[1.25^{\circ} \times 1.25^{\circ}\right](20)$} & 100 & Gordon et al. (2000) \\
\hline MIROC & {$\left[2.8^{\circ} \times 2.8^{\circ}\right](20)$} & {$\left[1.4^{\circ} \times 0.5^{\circ}\right](43)$} & 100 & K-1 model developers (2004) \\
\hline
\end{tabular}

Table 2. The frequency of occurrence (\%) of the Trough (T), Zonal (Z) and Blocking (B) regimes in the pre-industrial control (PI) and Mid-Holocene (MH) runs for each model. The change in the frequency of occurrence (\%) of each regime (DT, DB and DZ) for the MH relative to the PI is also included for each model. The frequency of occurrence of each regime, derived from NCEP reanalysis data from 1972-2009, are also given (seasonally) before the model values are stated.

\begin{tabular}{|c|c|c|c|c|c|c|c|c|c|}
\hline $\begin{array}{l}\text { Regime } \rightarrow \\
\text { Model / Season } \downarrow\end{array}$ & $\begin{array}{c}\mathrm{T} \\
\mathrm{PI}\end{array}$ & $\begin{array}{r}\mathrm{T} \\
\mathrm{MH}\end{array}$ & $\begin{array}{r}\text { DT } \\
\text { MH-PI }\end{array}$ & $\begin{array}{l}\mathrm{Z} \\
\mathrm{PI}\end{array}$ & $\begin{array}{r}\mathrm{Z} \\
\mathrm{MH}\end{array}$ & $\begin{array}{r}\text { DZ } \\
\text { MH-PI }\end{array}$ & $\begin{array}{l}\text { B } \\
\text { PI }\end{array}$ & $\begin{array}{r}\mathrm{B} \\
\mathrm{MH}\end{array}$ & $\begin{array}{r}\text { DB } \\
\text { MH-PI }\end{array}$ \\
\hline \multicolumn{10}{|l|}{ DJF } \\
\hline NCEP & 37.6 & & & 14.4 & & & 48.1 & & \\
\hline CSIRO Mk3L & 44.0 & 48.0 & $4.0^{*}$ & 17.8 & 13.6 & $-4.2^{*}$ & 38.2 & 38.4 & 0.2 \\
\hline ECHO-G & 42.4 & 39.7 & $-2.7^{*}$ & 20.1 & 17.3 & $-2.8^{*}$ & 37.5 & 43.0 & $5.5^{*}$ \\
\hline HadCM3_UB & 43.6 & 46.0 & $2.4^{*}$ & 14.5 & 11.0 & $-3.5^{*}$ & 41.9 & 43.1 & 1.2 \\
\hline MIROC & 43.4 & 45.3 & $1.9^{*}$ & 16.0 & 16.2 & 0.2 & 40.6 & 38.4 & $-2.2^{*}$ \\
\hline \multicolumn{10}{|l|}{ MAM } \\
\hline NCEP & 29.9 & & & 27.5 & & & 42.6 & & \\
\hline CSIRO Mk3L & 29.0 & 36.2 & $7.2^{*}$ & 33.0 & 29.4 & $-3.6^{*}$ & 37.9 & 34.5 & $-3.4^{*}$ \\
\hline ECHO-G & 29.0 & 42.3 & $13.3^{*}$ & 32.9 & 22.4 & $-10.5^{*}$ & 38.2 & 35.4 & $-2.8^{*}$ \\
\hline HadCM3_UB & 27.4 & 37.7 & $10.3^{*}$ & 29.0 & 18.2 & $-10.8^{*}$ & 43.1 & 44.1 & 1.0 \\
\hline MIROC & 24.6 & 33.4 & $8.8^{*}$ & 31.4 & 26.9 & $-4.5^{*}$ & 44.0 & 39.9 & $-4.1^{*}$ \\
\hline \multicolumn{10}{|l|}{ JJA } \\
\hline NCEP & 39.3 & & & 29.4 & & & 31.3 & & \\
\hline CSIRO Mk3L & 45.3 & 45.0 & -0.3 & 19.4 & 22.2 & $2.8^{*}$ & 35.3 & 32.8 & $-2.5^{*}$ \\
\hline ECHO-G & 44.6 & 40.9 & $-3.7^{*}$ & 18.5 & 22.3 & $3.8^{*}$ & 36.8 & 36.9 & 0.1 \\
\hline HadCM3_UB & 37.9 & 30.5 & $-7.4^{*}$ & 17.6 & 24.2 & $6.6^{*}$ & 44.4 & 45.3 & 0.9 \\
\hline MIROC & 44.0 & 40.6 & $-3.4^{*}$ & 25.0 & 23.8 & -1.2 & 31.0 & 35.6 & $4.6^{*}$ \\
\hline \multicolumn{10}{|l|}{ SON } \\
\hline NCEP & 43.1 & & & 30.0 & & & 26.8 & & \\
\hline CSIRO Mk3L & 34.6 & 26.5 & $-8.1^{*}$ & 35.3 & 41.1 & $5.8^{*}$ & 30.1 & 32.3 & $2.2^{*}$ \\
\hline ECHO-G & 38.7 & 29.8 & $-8.9^{*}$ & 39.2 & 48.9 & $9.7^{*}$ & 22.0 & 21.3 & -0.7 \\
\hline HadCM3_UB & 42.8 & 38.1 & $-4.7^{*}$ & 39.0 & 47.0 & $8.0^{*}$ & 18.3 & 15.0 & $-3.3^{*}$ \\
\hline MIROC & 46.8 & 39.5 & $-7.3^{*}$ & 29.7 & 36.0 & $6.3^{*}$ & 23.7 & 24.7 & 1.0 \\
\hline
\end{tabular}

Statistically significant $(\mathrm{p} \leq 0.05)$ changes are denoted with an *.

common to all, or most, of the models. While we accept that the models are subject to specific errors and biases, if the ensemble of models shows a coherent pattern of regime change it will increase our confidence in their representation of past climate. Each season will be analysed separately with respect to Table 2 and the pressure patterns in Figs. 3-6. The largest changes in the individual synoptic types (see Fig. 1) will also be discussed where appropriate, although exact values for these will not be quoted as they are used qualitatively to understand the SLP anomalies. Also, the results in this section will be compared to those of Rojas and Moreno (2011), who undertook a similar analysis with eleven GCMs to provide further context to our results. 


\subsection{DJF (summer)}

In DJF, all models except ECHO-G have a statistically significant increase in the number of trough synoptic types. Also, all models except MIROC have a statistically significant decrease in the zonal regime synoptic types. Similarly, Rojas and Moreno (2011) also found a slight decrease in SLP around New Zealand in DJF with increases towards the Antarctic, which agrees with the increases in troughs types.

The pressure anomaly maps for CSIRO Mk3L and MIROC (Fig. 3a and d) have a much more zonally symmetric increase in SLP throughout the SH high-latitudes with decreases to the north. The pattern is stronger in CSIRO Mk3L than MIROC, which explains why CSIRO Mk3L has a stronger increase in trough synoptic types than MIROC. However, while CSIRO Mk3L has an equivalent decrease in the zonal regime to the increase in the trough regime, MIROC does not, and loses blocking events to trough events.

For ECHO-G, high-latitude SLP is reduced in DJF for the $\mathrm{MH}$ compared to the PI, and the reduction in trough synoptic types agrees with the pressure pattern in Fig. 3b. However, the large (and statistically significant) high anomaly centred to the south and west of New Zealand (and extending to the east) agrees with the decrease in the zonal regime too, and consequently an increase in blocking (the majority of which come from HSE events).

Finally, HadCM3_UB has increases in trough synoptic types, in agreement with reduced SLP in the New Zealand region (Fig. 3c) and decreases in zonal synoptic types (similar to CSIRO Mk3L). However, the changes in SLP are much less zonally symmetric in HadCM3_UB than CSIRO Mk3L (compare Fig. 3a and c) and the overall changes in SLP are weaker, which agrees with the smaller magnitude values of DT and DZ in Table 2 for HadCM3_UB.

\subsection{MAM (autumn)}

The MAM changes in the synoptic regimes are stronger and more coherent across all of the models than in any other season (and the season for which the models are in best agreement with NCEP). All the models have a statistically significant increase in troughs and a decrease in zonal synoptic types, with three out of the four models also having a statistically significant decrease in blocking occurrence (see Table 2). Rojas and Moreno (2011) also found large decreases in SLP at mid-to-low-latitudes in the SH, with increases in SLP towards higher SH latitudes.

The changes in the synoptic regimes also agree very well with the changes in the pressure patterns in all of the models (Fig. 4a-d). All models have an increase in SLP throughout the SH high-latitudes in the MH compared to PI, with strong decreases in SLP centred to the east of New Zealand, which extend throughout much of the SH mid-latitudes. While all of the models have increased trough frequency, the models with the more zonally symmetrical changes in SLP (CSIRO
Mk3L, ECHO-G and MIROC - Fig. 4a, b and d) have the largest increases in T events, whereas HadCM3_UB (which is much less zonally symmetric, Fig. 4c) has the largest increase in TSW events.

All the models have a large reduction in the occurrence of $\mathrm{H}$ (zonal) and HSE (blocking) events, which agrees with the general pattern of reduced pressure in the New Zealand region. However, the loss of H events in HadCM3_UB is countered by an equal increase in R-type patterns, which suggests that the wave number three pattern in Fig. $4 \mathrm{c}$ is not a stationary feature, and high anomalies can propagate from west to east across New Zealand.

\subsection{JJA (winter)}

In JJA all models have a decrease in the frequency of troughs, of which three have a statistically significant decrease (see Table 2). Also, three of the four models have a statistically significant increase in the zonal regime.

The changes in SLP for the MH relative to the PI are more complex for each of the models than in any of the previous seasons (see Fig. 5a-d). The three models that have a statistically significant reduction in troughs all have increases in SLP for the MH compared to the PI (ECHO-G, HadCM3_UB and MIROC in Fig. 5b-d) close to New Zealand. The CSIRO Mk3L model, however, has a decrease in the number of blocking synoptic types and an increase in zonal synoptic types. The largest contributor to this change is a decrease in the number of HSE and NE events, and an increase in H events, which agrees with increased (decreased) SLP to the west (east) of New Zealand in Fig. 5a.

The ECHO-G and HadCM3_UB models also have more $\mathrm{H}$ events (particularly in HadCM3_UB) but ECHO-G also has a similar increase in HNW events too, which agrees with the high SLP anomaly in Fig. 5b being displaced more to the west than in Fig. 5c. Finally, the MIROC model has less HNW and W events, which agrees with the southern displacement of the high SLP anomaly in Fig. 5d, with the increase in blocking caused mainly by an increase in HSE events.

The increase in zonal synoptic types initially appears to be in direct disagreement with the results of Rojas and Moreno (2011), as zonal synoptic types are typically associated with an increased north-south pressure gradient across New Zealand and increased westerlies, whereas Rojas and Moreno (2011) suggest that the westerlies were weaker. However, as stated above, the largest increases within the zonal regime were for the "H" synoptic type (see Fig. 1), which indicates high pressure centred just to the west of the North Island but influencing the flow over the whole of New Zealand. This is likely to reduce the surface westerlies over New Zealand and is consistent with Rojas and Moreno (2011). Generally, zonal synoptic regimes are associated with high SLP centred to the north of $40^{\circ} \mathrm{S}$, and during JJA the South Pacific Anticyclone (SPAC) is at its most 
(a) CSIRO

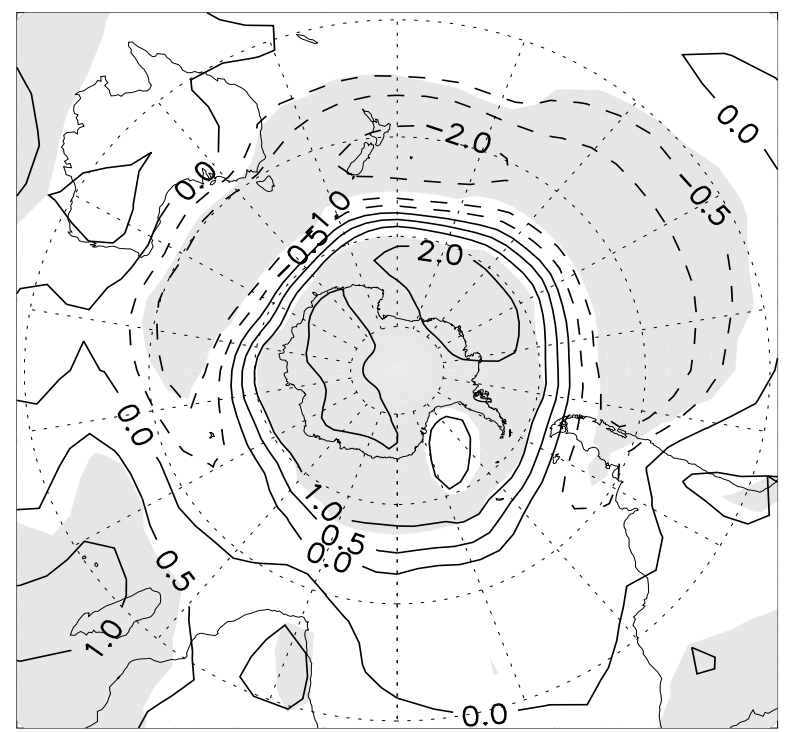

(c) HadCM3_UB

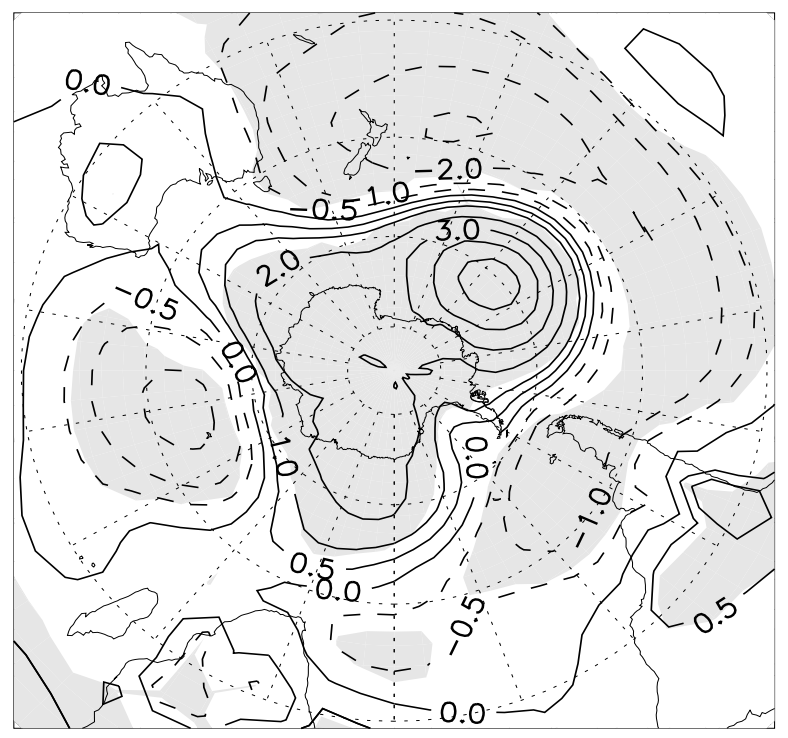

(b) $\mathrm{ECHO}-\mathrm{G}$

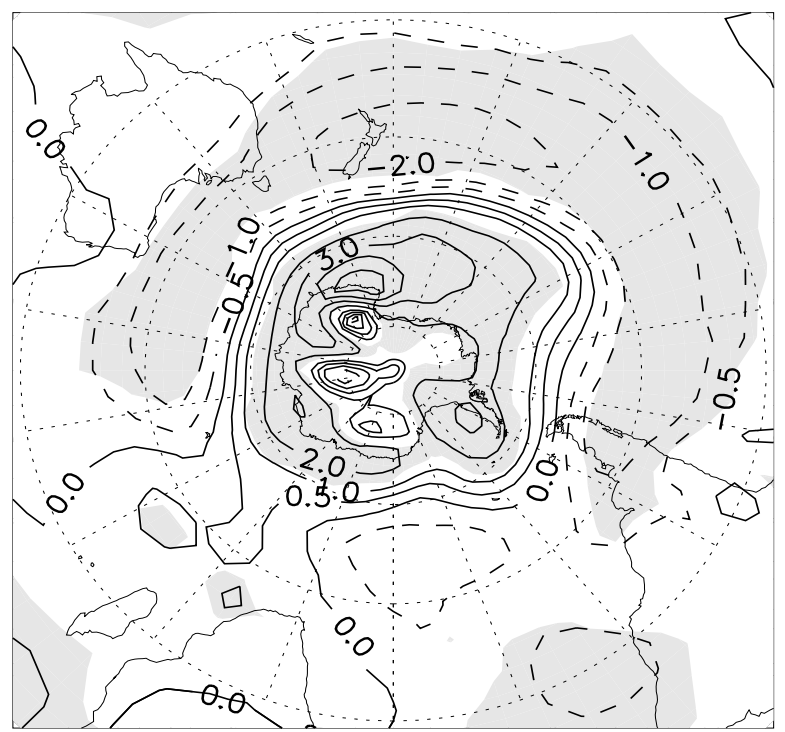

(d) MIROC

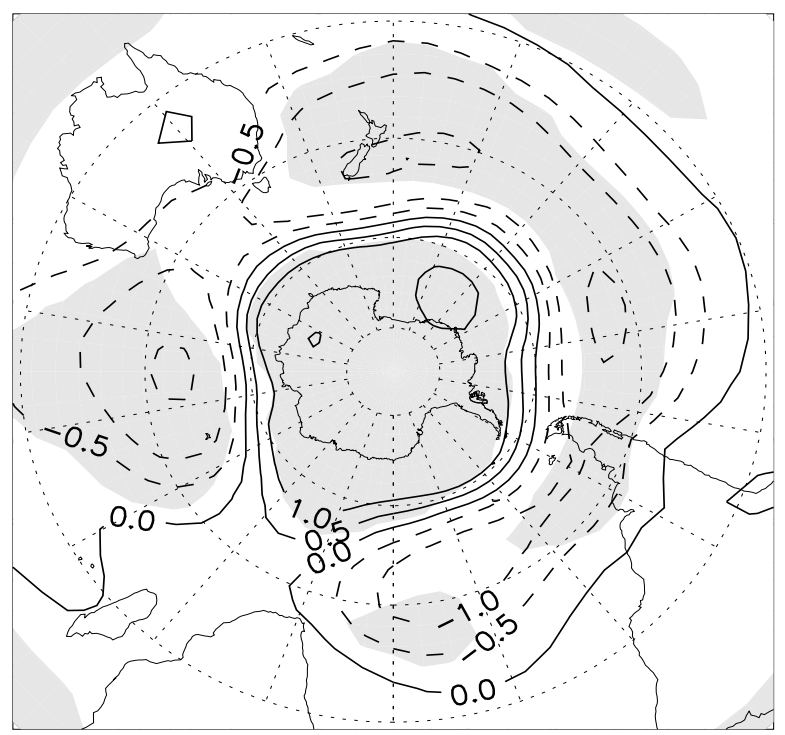

Fig. 4. The same as Fig. 3 except for MAM. 
(a) CSIRO

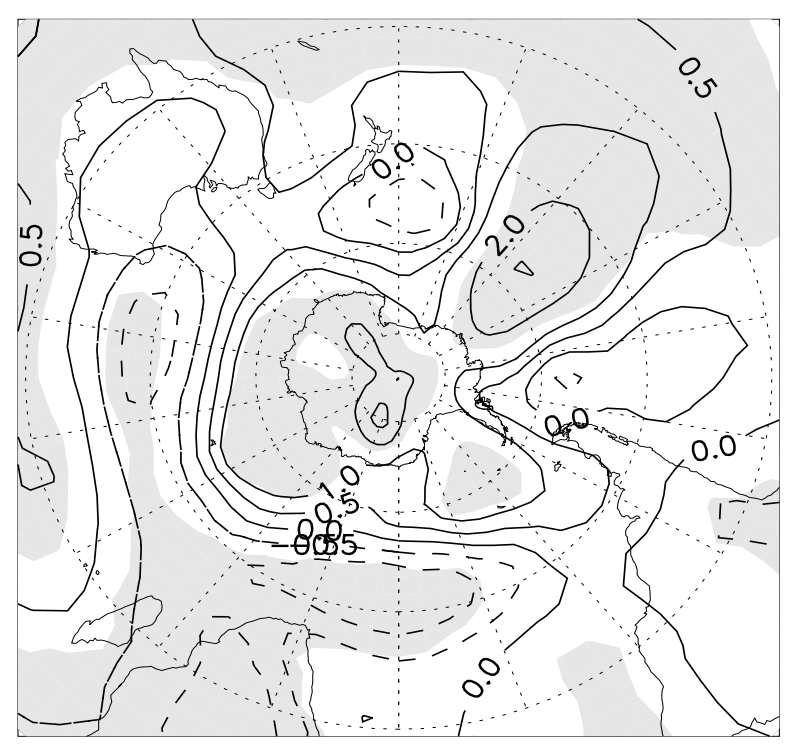

(c) HadCM3_UB

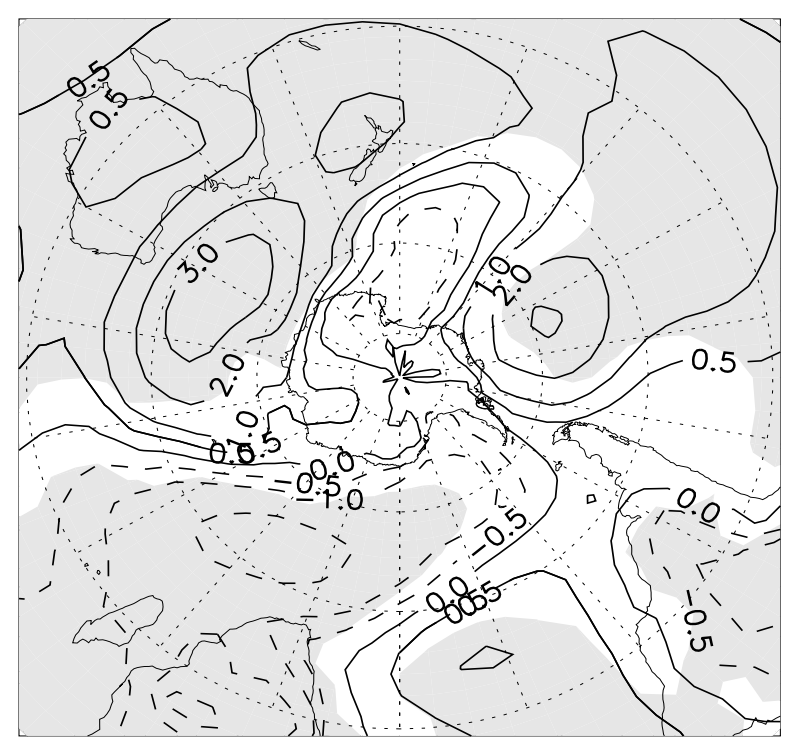

(b) $\mathrm{ECHO}-\mathrm{G}$

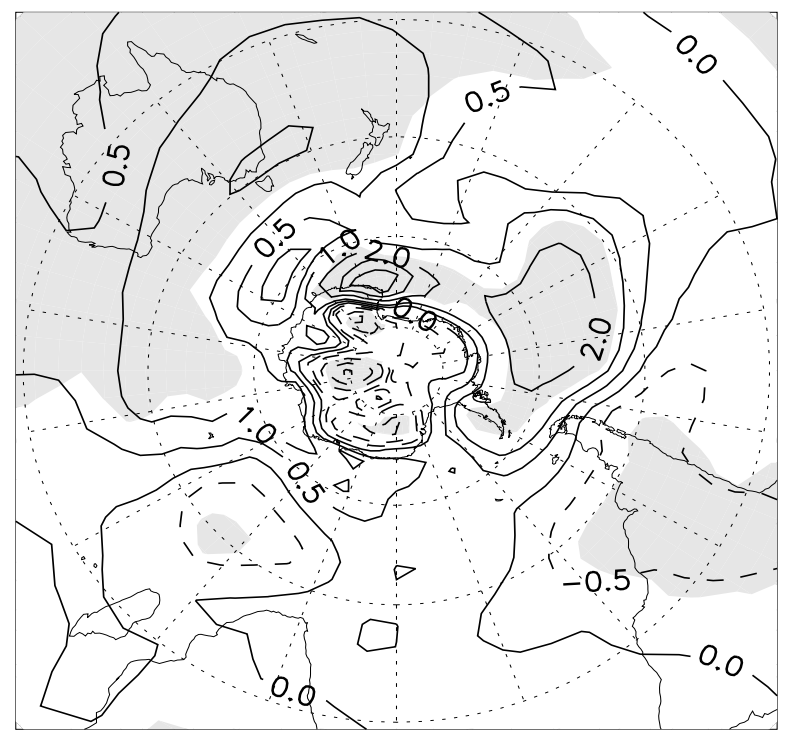

(d) MIROC

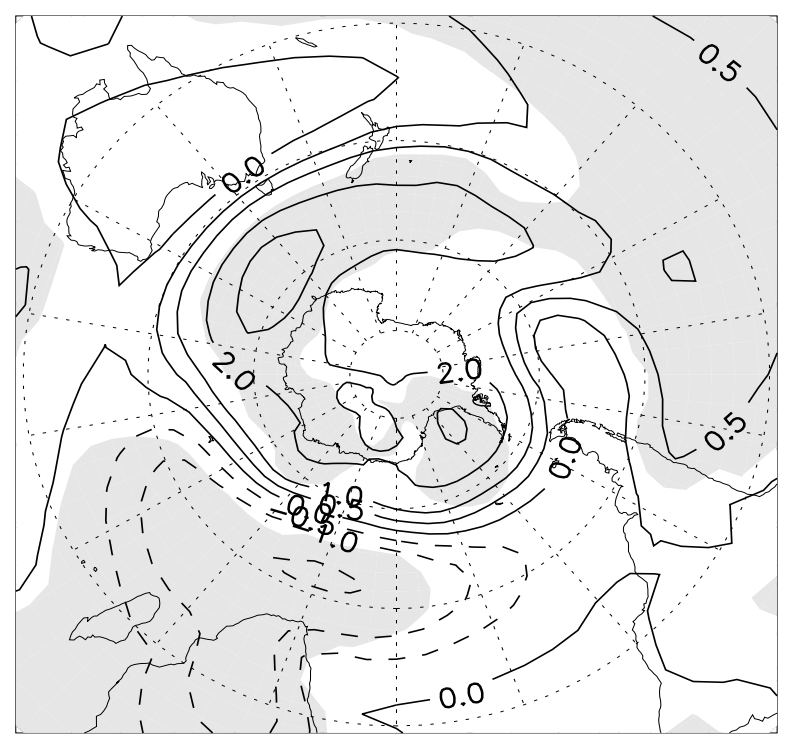

Fig. 5. The same as Fig. 3 except for JJA 
(a) CSIRO

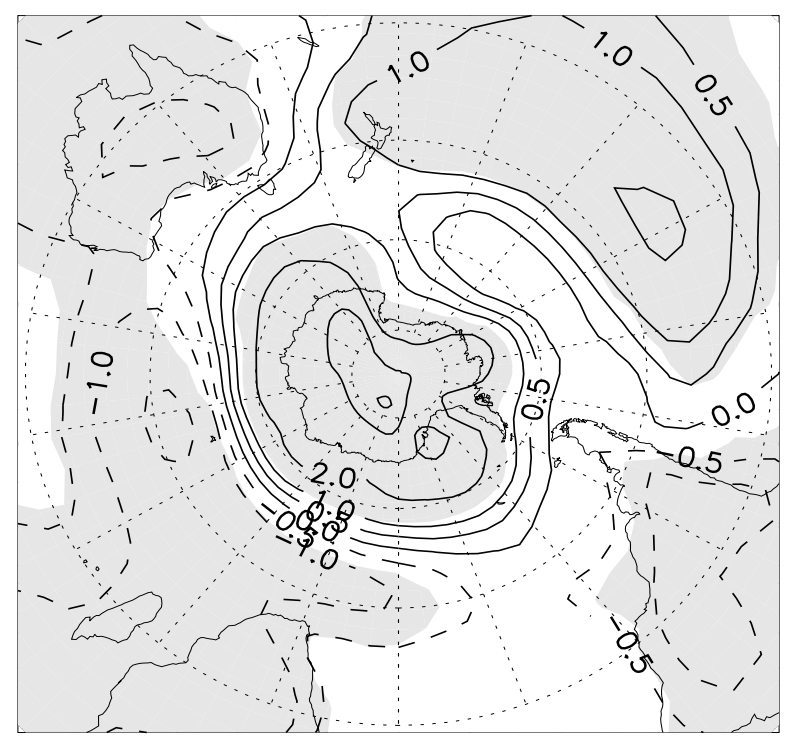

(c) HadCM3_UB

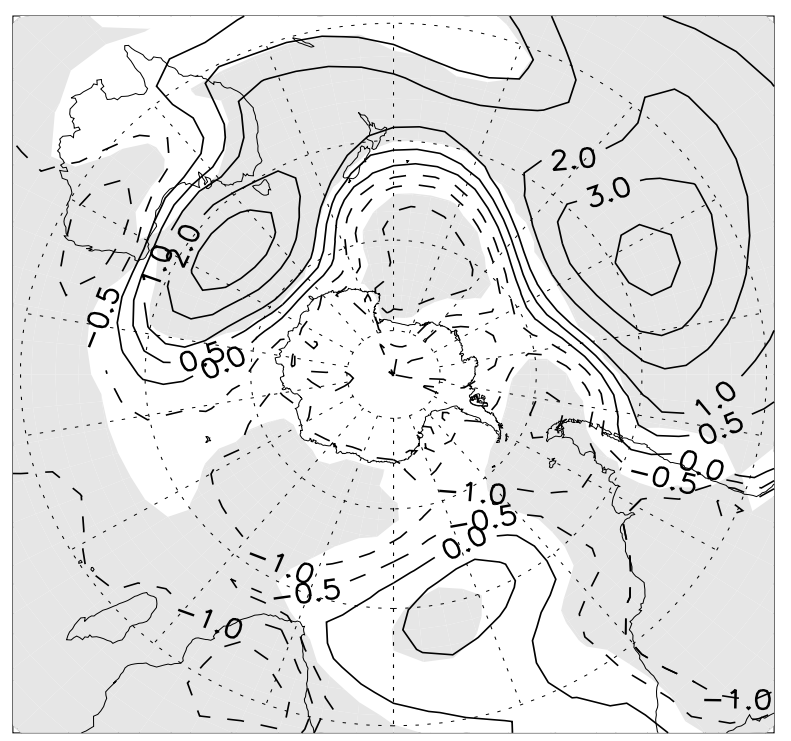

(b) $\mathrm{ECHO}-\mathrm{G}$

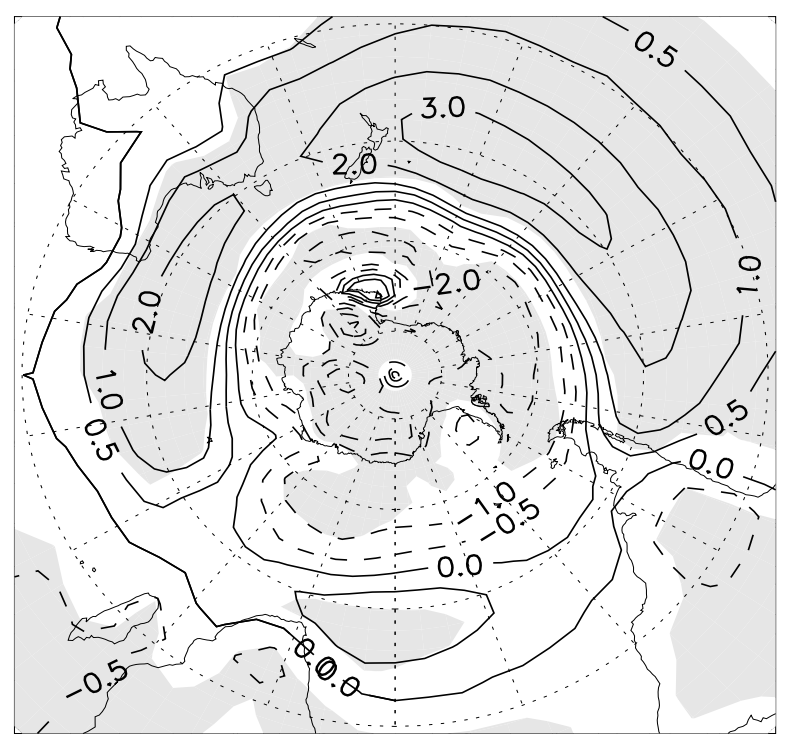

(d) MIROC

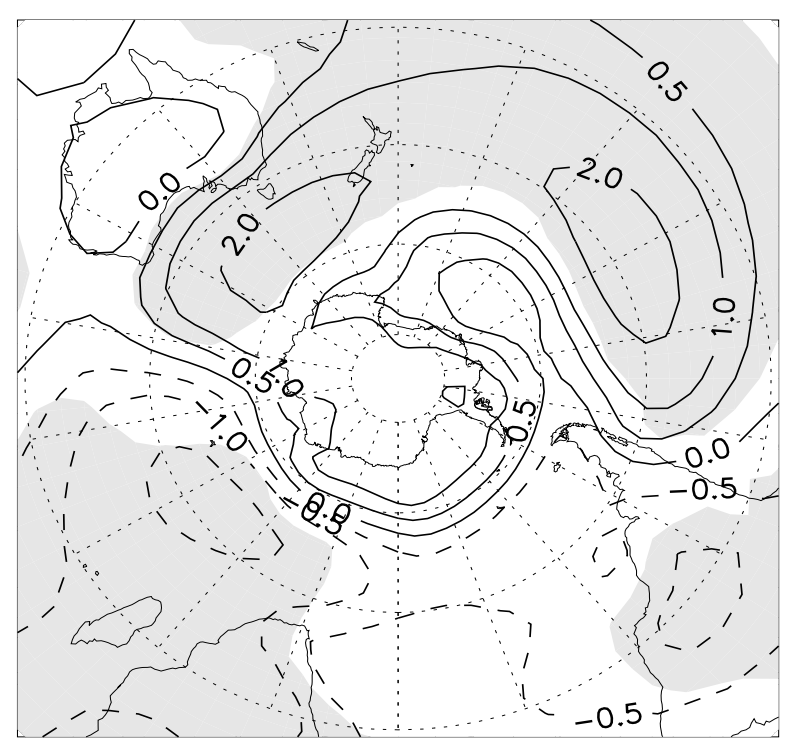

Fig. 6. The same as Fig. 3 except for SON 
equatorward location. Therefore, the slight intensification of the SPAC seen in Rojas and Moreno (2011) (their Fig. 3e), while centred at its most equatorward in JJA, leads to high pressure located north of $40^{\circ} \mathrm{S}$, which is why the synoptic classification analysis suggests more zonal flow in JJA despite the weak changes in SLP. The seasonality of these circulation patterns is important when considering the outcome of the synoptic classification analysis.

\subsection{SON (spring)}

For SON, all of the models have a decrease in the frequency of troughs and an increase in the frequency of zonal synoptic types, which are all statistically significant (and large in magnitude), and which agrees with Rojas and Moreno (2011). While ECHO-G and MIROC do not have statistically significant changes in the blocking regime, both CSIRO Mk3L (increase) and HadCM3_UB (decrease) do. The causes of these differences can be understood by looking at the changes in SLP for the MH compared to the PI, and also by identifying which of the individual synoptic types in Fig. 1 have changed the most. The changes in SLP for SON are given in Fig. 6, and (in all cases) there are increases around New Zealand, which agrees with the reduction in troughs. While ECHO-G and HadCM3_UB have a reduction in high-latitude SLP (see Fig. $6 \mathrm{~b}$ and c), CSIRO Mk3L and MIROC (Fig. 6a and d) indicate an increase.

In all models, the frequencies of $\mathrm{H}$, HNW and $\mathrm{W}$ synoptic types increase from PI to $\mathrm{MH}$ (particularly in $\mathrm{H}$ and $\mathrm{HNW}$ ), and all synoptic types in the trough regime decrease for all models except HadCM3_UB. In HadCM3_UB there is a strong increase in the frequency of the SW type and a decrease for all synoptic types in the blocking regime, which agrees with the pressure anomaly pattern in Fig. 6c. In CSIRO Mk3L, there are strong increases in the HSE and HE types for blocking, which agrees with the high pressure anomaly situated to the east of New Zealand in Fig. 6a. In MIROC, however, (which has a similar SLP anomaly pattern to CSIRO Mk3L, Fig. 6d) the increases in HSE and HE events are offset by reductions in NE and R. Finally, while ECHO-G has a reduction in high-latitude SLP in SON (Fig. 6b), the SLP anomalies are more zonally symmetric, which causes a decrease (increase) in trough (zonal) types with little change to the occurrence of blocking types.

\subsection{Summary}

Generally, the climatic pattern from the results given above implies more "disturbed" conditions (i.e. either strengthened westerlies or more unsettled "trough" conditions) for New Zealand during the Mid-Holocene compared to the preindustrial simulations. The models indicate an increase in zonal types in JJASON (which may imply strengthened westerlies in SON but not necessarily in JJA see Sect. 3.3), and more trough events in DJFMAM may result in generally more unsettled conditions in New Zealand. The lack of a coherent seasonal signal in the blocking regime (except in MAM where three of the four models have a decrease in blocking events) also agrees with the more 'disturbed' pattern near New Zealand during the Mid-Holocene.

\section{Implications for New Zealand}

\subsection{Downscaled changes in temperature and precipitation}

Having identified how the synoptic regimes differed seasonally in the MH compared to the PI in the GCMs, we can infer how the seasonal climate may have been different in New Zealand during the Mid-Holocene. Originally, Kidson (2000) estimated the anomalies in temperature and precipitation associated with each synoptic regime, regionally for New Zealand from monthly mean data. Trough events were associated with generally wetter conditions throughout New Zealand and cooler conditions in the south. Zonal events are associated with drier conditions in the north and east of New Zealand, with warmer conditions in the south. Finally, blocking events were associated with generally warmer temperatures throughout New Zealand, with reduced precipitation except in eastern parts of both the North and South Islands and the north of the North Island. Updated versions of these anomalies can also be seen in the supplementary material for this paper (see Renwick, 2011)

The analysis undertaken by Kidson (2000) was repeated in this study using daily SLP data from the NCEP/NCAR reanalysis and daily temperature and precipitation data from the Virtual Climate Station Network (VCSN, see Tait et al., 2006, for a description of the methodology) in New Zealand from 1972 to 2009 . The daily VCSN fields were averaged by regime type and season to produce a mean field of temperature and rainfall anomalies (differences from normal) for the present day (as can be seen in Renwick, 2011, see Supplement). To derive the changes in surface climate anomalies associated with modelled Mid-Holocene climate, we calculated weighted averages of the individual regime mean fields. The weights were the changes in percentage frequency of occurrence of each regime (from Table $2-$ DT, DZ and DB) between Mid-Holocene and pre-industrial from each of the model runs. Ensemble mean anomalies were calculated by averaging individual results across all the models, as shown by season in Figs. 7 and 8, for temperature and precipitation, respectively.

The higher incidence of trough events in MAM during the Mid-Holocene causes an increase in surface air temperature throughout the North Island (particularly in the east) and a decrease throughout much of the South Island (particularly in the south and west), as can be seen in Fig. 7. The warming in the North Island appears to be counter-intuitive with the annual mean results of Kidson (2000). However, Renwick 
(2011) indicates that the surface air temperature anomalies associated with the trough regime have a strong seasonal dependence that leads to an overall warming in the North Island during the colder seasons (such as JJA or MAM), which is consistent with the results presented here. Conversely, the higher incidence of zonal synoptic types in SON during the Mid-Holocene induces a slight cooling in parts of the North Island and warming in the South Island (again, particularly in the south and west). In both cases (MAM and SON), the warming and cooling are $\sim 0.2^{\circ} \mathrm{C}$ in magnitude and even weaker in DJF and JJA.

The values in Fig. 7 only account for the temperature changes caused by differences in circulation, whereas the model data includes changes in temperature from a combination of circulation and insolation differences. While the low resolution of the models does not allow us to understand the fine structure of the temperature changes, large scale cooling or warming, primarily driven by changes in insolation, may enhance or reduce the temperature variations seen in Fig. 7. The suggestion from the models is that surface air temperatures in the New Zealand region were at least $0.2^{\circ} \mathrm{C}$ cooler in DJF through to JJA (not shown) due to circulation changes and reduced insolation (see Fig. 2 for insolation changes), which suggests that the reduced insolation may have the dominant effect on temperature in DJF to JJA. In SON, the models suggest a small warming around New Zealand of $\sim 0.1{ }^{\circ} \mathrm{C}$ due to changes in circulation and increased insolation, which suggests that the insolation increases in SON (see Fig. 2) may slightly enhance the South Island warming seen in Fig. 7. These results from the four GCMs here (cooling in DJF, MAM and JJA and warming in SON only around New Zealand) are consistent with the results of analysing the eleven GCMs in Rojas and Moreno (2011), further suggesting that the effects of the imparted insolation changes (MH relative to PI, see Fig. 2) on surface air temperature are stronger than those induced by the circulation changes.

Despite the overall South Island warming in SON, the influence of HNW synoptic types relative to W types (noted in Sect. 3.4) suggests an increase in southwesterly flow over New Zealand during SON relative to westerly and northwesterly flow. While the tendency is for a warmer South Island during SON (see Fig. 7) in the Mid-Holocene, HNW types are associated with increased frost occurrence (not shown) throughout the southern and western South Island in particular. Therefore, New Zealand may have been prone to more frequent frost outbreaks during spring in the MidHolocene relative to the present, despite the overall tendency for warmer conditions in the South Island. The weakest overall anomalies occur during DJF, where there are only very small changes in temperature resulting from the increases in trough synoptic types.

Overall, it seems likely that the seasonal insolation changes (see Fig. 2) may have had a larger influence on surface air temperature than the changes in the synoptic regimes.
However, the high spatial variability of the changes in temperature given in Fig. 7 indicates that the synoptic regimes may have enhanced or reduced the magnitude of the temperature responses to the changes in insolation. The coarse resolution of the GCMs does not allow us to investigate these local changes.

Whereas the differences in temperatures were quite weak, the precipitation anomalies associated with the MidHolocene climate regimes are more prominent (Fig. 8). The increase in trough occurrence for MAM during the MidHolocene suggests that increased precipitation was more likely throughout New Zealand compared to present day. Similarly, there are positive precipitation anomalies throughout New Zealand in DJF too, which indicates a wetter DJFMAM than at present associated with the increase in the trough regime. However, the increase in the frequency of zonal events causes a strong drying for many parts of the North and South Islands in SON, although the drying is reduced (or even reversed) in the far south and west of the South Island. A similar pattern can also be seen in JJA (albeit weaker), in agreement with the smaller changes in Table 2. Overall, the model output suggests wetter conditions throughout New Zealand in DJFMAM and drier conditions during JJASON, which agrees with the suggested reduction in SH seasonality identified in Braconnot et al. (2007) and Rojas and Moreno (2011) for the Mid-Holocene.

\subsection{Implications from the New Zealand palaeoclimate record}

A suite of proxy reconstructions of environmental change from across New Zealand were recently summarised by $\mathrm{Li}$ et al. (2008), who suggested national-scale precipitation and temperature regime changes occurred in the Mid-Holocene. They demonstrated a key environmental shift occurred in the Mid-Holocene, and suggested this change was a causal mechanism for vegetation change at Sponge Swamp in the western South Island (WSI) regional climate district. At that site, a significant drop in the pollen representation of the small tree Ascarina lucida began at $\sim 6.9 \mathrm{ka}$, and there was also a change in peat deposition beginning at $\sim 6.4 \mathrm{ka}$. The interpretation of the Ascarina change follows multiple studies (McGlone and Moar, 1977; McGlone et al., 1988; Newnham et al., 1989; Martin and Ogden, 2002, 2005) that demonstrate this species needs warm and wet conditions (with limited frost exposure) to survive, and regeneration is dependent on disturbance events. Similarly, the decline or disappearance of Ascarina can also be used to imply a shift to cooler or drier times, increased frost incidence or low disturbance. The interpretation provided by $\mathrm{Li}$ et al. (2008), indicative of reduced humid northerly flow and increased southwesterlies, is similar to that of McGlone et al. (1993), who suggested at some time between the early Holocene and $\sim 7.5$ to $\sim 3 \mathrm{ka}$, key environmental shifts occurred in many northern and western areas of the country, with the onset of 


\section{Ensemble mean: Mean temperature anomaly $\left({ }^{\circ} \mathrm{C}\right)$}
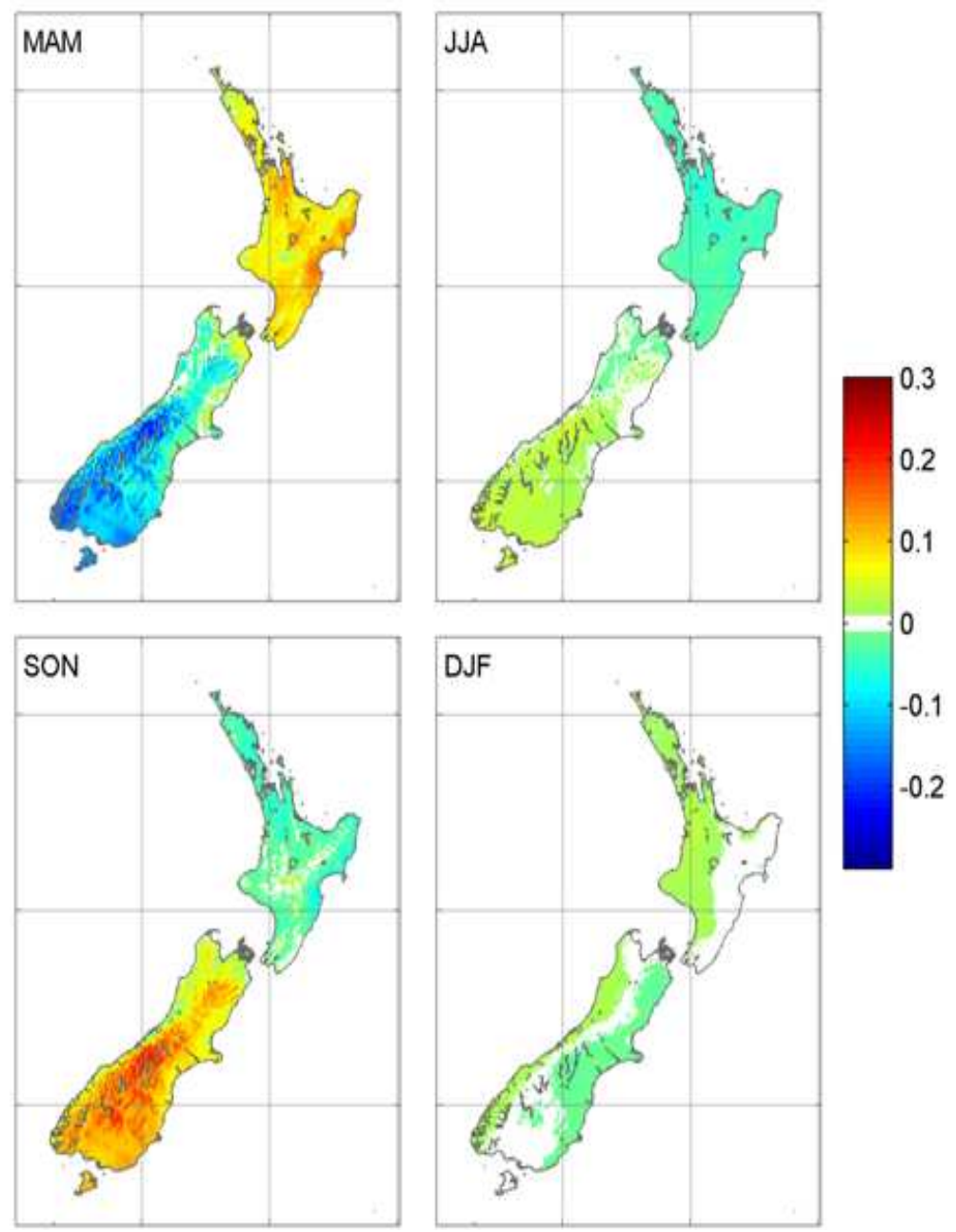

Fig. 7. The ensemble mean change in surface air temperature $\left({ }^{\circ} \mathrm{C}\right)$ associated with the changes in the frequencies of occurrence given in Table 2 for the MH relative to the PI during MAM, JJA, SON and DJF.

wetter winters, a slight cooling in climate, and an increase in southerly fronts and frosts in New Zealand.

Pollen profiles from interior Canterbury adjacent to the eastern edge of the WSI climate district (Burrows and Russell, 1990) and in the Takitimu Mountains in Southland (Vandergoes et al., 1997) show elevated pollen from Prumnopitys taxifolia (matai; a tall conifer) in the early Holocene. $P$. taxifolia environmental affinities in New Zealand tree distribution models indicate it reaches maximum abundance in drought-prone climates at sites with large air saturation deficits (Leathwick and Whitehead, 2001). The pollen abundance of this species has also been interpreted as past dry periods (Horrocks and Ogden, 1998), suggesting the WSI experienced significant dry anomalies prior to $6 \mathrm{ka}$. P. taxifolia declined in sync with a rise of Nothofagus menziesii at many sites in the WSI after $\sim 6$ ka (Harris, 1963; McGlone and Bathgate, 1983; Burrows and Russell, 1990; Vandergoes et al., 1997).

Lorrey et al. (2008) recently provided an overview of the way $N$. menziesii and P. taxifolia could be employed as contrasting climate change indicators. N. menziesii (silver beech) is a frost tolerant species that can survive sub-zero temperatures (Neuner et al., 1997; Sun and Sweet, 1996). It is also a drought-intolerant species, which may lead to its exclusion from lowland sites in warm, dry areas throughout New Zealand (Manson, 1974). Mass mortality of this type of tree has also been attributed to severe drought episodes (Jane and Green, 1983, 1984). The combination of frost tolerance and drought intolerance results in $N$. menziesii being the most abundant Nothofagus species at high altitude sites with poor soil drainage (Ogden et al., 1996). While temperature may play a role in determining the distribution of $N$. menziesii, 


\section{Ensemble mean: Rainfall anomaly (\%)}
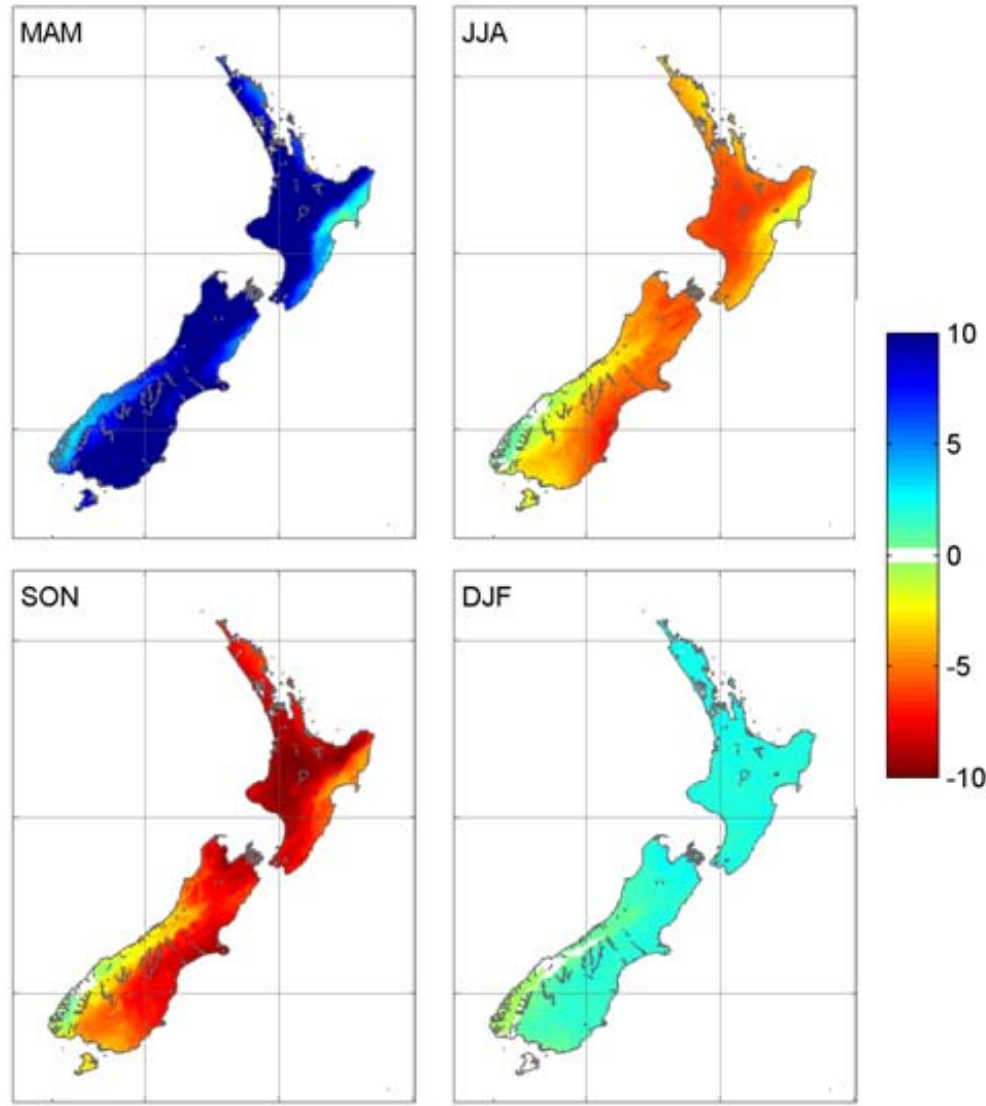

Fig. 8. The same as Fig. 7 except for the precipitation anomaly (\%).

the defining environmental differences of $N$. menziesii and $P$. taxifolia, and one reason for their apparent contrast in pollen diagrams covering the Mid-Holocene, appear to relate to their drought tolerances. Both species can be abundant at cold sites or during periods of reduced temperatures, but $N$. menziesii is abundant at sites where soil water deficits are rare, and $P$. taxifolia thrives in drought-prone regions or in drier climatic intervals. The beech expansion and $P$. taxifolia decrease seen in the Mid-Holocene at approximately $6 \mathrm{ka}$, along with the other evidence summarised by Li et al. (2008) and McGlone et al. (1993), indicate a circulation shift occurred that supported a change from drier to wetter conditions in the WSI. Decreased tall tree pollen and increased Coprosma (and other small trees/shrubs) along with observations of woody debris layers in peat cores from the southern South Island also suggest increased disturbance due to more frequent westerly wind storms and more precipitation in WSI during the Mid-Holocene (McGlone and Bathgate, 1983). In addition, Schaefer et al. (2009) have presented cosmogenic surface exposure age dates for the Tasman and Mueller glaciers that indicate an ice advance occurred at ap- proximately $6520 \pm 360 \mathrm{yr}$ ago. This also suggests a climate regime change that favoured lower temperatures and increased precipitation in WSI (weighted to summer) would have occurred in the Mid-Holocene close to $\sim 6 \mathrm{ka}$.

Overall, the palaeo-vegetation and glacial evidence suggests a circulation regime shift (albeit non-synchronous at many sites due to differing chronological controls and sample resolution employed for the palaeoclimate archives) that favoured more frequent westerly and southwesterly circulation, which are hallmarks of zonal and trough synoptic types. Increased zonal and trough events would have brought an increase in precipitation in western and southern regions, an increase in the occurrence of southerly fronts, cooler temperatures and increased incidence of frost for WSI at $\sim 6 \mathrm{ka}$. This palaeoclimate evidence is consistent with increased zonal and trough activity observed in the palaeoclimate model simulations presented in this study. The palaeoclimate evidence summarised here and the results from the model synoptic type frequency comparison reconcile a critical proxy-model discrepancy previously noted by McGlone et al. (1993). In that study, CLIMAP SST results suggested 
increased seasonality and decreasing westerly windflow at $\sim 6000 \mathrm{yr}$ before present in the New Zealand sector, while land-based palaeovegetation records implied increased seasonality, increased windiness, and increased southerly quarter windflow. Our results are based on the outputs of models which comprise more complete descriptions of the physical climate system, have finer spatial resolution, and have more detailed information about atmospheric circulation patterns relative to the CLIMAP results. The palaeoclimate model ensemble collectively indicates that an increase in westerly and southerly quarter flow due to more frequent trough and zonal circulation was likely at $\sim 6 \mathrm{ka}$, and the proposed circulation change agrees with precipitation- and temperature-sensitive climate proxies for the same time period. On a larger spatial scale, the timing of a Mid-Holocene transition, observed in New Zealand, to increased westerly and southerly quarter influences was also seen in Chile (Lamy et al., 2001). We hypothesise that the similar timing of changes observed at distal locations across the Pacific Basin (that include the regionally-distinct, synoptic circulationdriven shifts in New Zealand at $\sim 6 \mathrm{ka}$ ) were nested within a large-scale hemispheric-scale circulation mode. Future efforts to expand the regional climate regime classification approach (Lorrey et al., 2007, 2008) across the Southern Hemisphere, and a subsequent comparison of the proxy-based patterns with large scale palaeoclimate model results, could help to reveal the timing and refine the character of distinct hemispheric-circulation modes that occurred in the past.

\section{Conclusions}

This study has shown that the seasonal circulation characteristics over New Zealand were different during the MidHolocene compared to the pre-industrial era but that the patterns between the four GCMs are mostly coherent. However, while the changes in the synoptic regimes are consistent between the models, the individual weather types contributing the most to those changes (as discussed in Sects. 3.1-3.4) are different. Overall, the strongest changes in the circulation occurred in MAM and SON, with weaker differences in DJF and JJA.

There were statistically significant increases in troughs for all models during MAM and for three of the four models during DJF. The changes in the regimes resulted in increased precipitation during DJFMAM and cooler South Island temperatures in MAM. There were also statistically significant increases in zonal types for all models during SON and for three out of four models in JJA. The increase in zonal flow is likely to have caused drying throughout much of New Zealand in JJASON (except in the western South Island) and warming of the South Island in SON. However, the combination of increased trough events in DJFMAM and zonal events in JJASON may have caused increased rainfall throughout the year in the extreme south and west of the South Island and an overall depression in mean annual temperature. Nonetheless, the estimated changes in temperature are only based on changes in circulation and do not account for the changes in insolation.

Overall, the circulation induced precipitation and temperature anomalies inferred from the synoptic regime analysis in DJFMAM and JJASON may cancel out over most of New Zealand when considering the annual mean. This is similar to the results seen for the modern reanalysis period, which indicate that the most significant climate regime shifts were on sub-annual time scales, and that there was no statistically significant change in synoptic type frequency when comparing annual statistics for opposite IPO phases (Lorrey et al., 2007). However, the suggestions from the proxy reconstructions discussed in Sect. 4.2 are that:

- There was a shift to cooler conditions at some point during the Mid-Holocne close to $\sim 6 \mathrm{ka}$, likely to be driven by the reduction in insolation from December to May.

- Conditions were likely to have been more "disturbed".

- Lower temperatures, increased incidence of frost and increased precipitation in the western South Island resulted from circulation change.

Despite an overall lack of change in the frequency of occurrence of each of the weather regimes (as the seasonal differences cancel somewhat), the inferred climate from the proxy reconstructions is consistent with the model output. While there is no evidence that circulation changes alone give rise to cooler temperatures in the models, there is evidence for a cooler autumn in the South Island induced by the circulation changes. Another contributing factor may have been the difference in the Earth's orbital parameters during the MidHolocene, which caused lower insolation for the SH during DJFMAM and may have led to further cooling. However, the synoptic regime analysis cannot account for the effects of changing the insolation on surface air temperature and remains a limitation of this method. This is supported by the work of Rojas and Moreno (2011), who show that there is an overall annual mean cooling around New Zealand induced by the changes in insolation and circulation for the Mid-Holocene relative to the pre-industrial. This highlights the limitation of estimating the changes in surface temperature from the synoptic classification method, which by assuming uniformitarian principles, cannot account for the effects of insolation. Also, despite the suggested warming in the South Island from the changes in the modelled regimes, the increase in HNW synoptic types may have increased frost occurrence in spring (particularly in the western South Island), which also agrees with the proxy data. However, due to the low resolution of the GCMs used in this study, they are not able to represent the detailed topographical features of New Zealand and so we cannot confirm the changes in regional precipitation and temperature across New Zealand 
directly from the models. Further improvement could be attained with the use of dynamical downscaling (for example with a regional climate model), which would also include the different solar forcing of the Mid-Holocene compared to the present day. However, dynamical downscaling is beyond the scope of this paper.

There is also evidence in the models for year-round disturbance (in agreement with the proxy data), with increases in trough regime influence in DJFMAM and zonal regime predominance in JJASON. There is little consensus between the models for changes in blocking frequency. Therefore, despite there being little change annually to the synoptic regimes (and subsequently temperature and precipitation inferrred from this study), there is evidence for more unsettled conditions in DJFMAM and intensified westerly winds in JJASON.

Despite the low resolution, the classification of synoptic weather types into climate regimes and associated qualitative downscaling to regional climate variability (including the regionally contrasting patterns that arise from orographic effects) is a first step in understanding the possible changes in New Zealand climate during the Mid-Holocene and identifying underlying causes of the changes. The method used in this study will also allow us to compare the model output with proxy time slices that are generated in a similar manner to Lorrey et al. (2007). Also, the use of GCM simulations to undertake dynamical downscaling (for example using a regional climate model) may add further insight into the climate of New Zealand during the Mid-Holocene.

\section{Supplementary material related to this article is available online at: http://www.clim-past.net/7/1189/2011/ cp-7-1189-2011-supplement.pdf.}

Acknowledgements. This work contributes to the Adaptation to Climate Variability and Change programme (contracts C01X0202 and C01X0701), Modelling Palaeoclimate to Inform the Future programme (contract UOAX0213), and the Regional Climate Modelling to Develop Probabilistic Scenarios of Future New Zealand Climate (contract C01X0804) programme undertaken at NIWA (Wellington and Auckland). The authors would also like to thank Georgina Griffiths (NIWA Auckland) for providing useful input in reviewing a draft version of this paper.

Edited by: V. Rath

\section{References}

Ackerley, D. and Renwick, J. A.: The Southern Hemisphere semiannual oscillation and circulation variability during the MidHolocene, Clim. Past, 6, 415-430, doi:10.5194/cp-6-415-2010, 2010.

Burrows, C. J. and Russell, J. B.: Aranuian vegetation history of the Arrowsmith Range, Canterbury I. Pollen diagrams plant macro- fossils, and buried soils from Prospect Hill, New Zeal. J. B., 28, 323-345, 1990.

Braconnot, P., Otto-Bliesner, B., Harrison, S., Joussaume, S., Peterchmitt, J.-Y., Abe-Ouchi, A., Crucifix, M., Driesschaert, E., Fichefet, Th., Hewitt, C. D., Kageyama, M., Kitoh, A., Laîné, A., Loutre, M.-F., Marti, O., Merkel, U., Ramstein, G., Valdes, P., Weber, S. L., Yu, Y., and Zhao, Y.: Results of PMIP2 coupled simulations of the Mid-Holocene and Last Glacial Maximum Part 1: experiments and large-scale features, Clim. Past, 3, 2610277, doi:10.5194/cp-3-261-2007, 2007.

Gordon, C., Cooper, C., Senior, C. A., Banks, H., Gregory, J. M., Johns, T. C., Mitchell, J. F. B., and Wood, R. A.: The simulation of SST, sea-ice extents and ocean heat transports in a version of the Hadley Centre Model without flux adjustments, Clim. Dynam., 16, 147-168, 2000.

Harris, W. F.: Palaeo-ecological evidence from pollen and spores, Proceedings of the New Zealand Ecological Society, 10, 38-44, 1963.

Horrocks, M. and Ogden, J.: Fine resolution palynology of Gibsons' Swamp, central North Island, New Zealand, since c 13000 B.P., New Zeal. J. B., 36, 273-283, 1998.

Jane, G. T. and Green, T. G. A.: Episodic forest mortality in the Kaimai Ranges, North Island, New Zealand, New Zeal. J. B., 21, 21-31, 1983.

Jane, G. T. and Green, T. G. A.: Ecological aspects of climate patterns within the Kaimai Ranges, North Island, New Zealand, New Zeal. J. Ecol., 7, 183-197, 1984.

Joussaume, S. and Taylor K. E.: The Paleoclimate Modeling Intercomparison Project: Proceedings of the third PMIP workshop, in: WCRP-111, WMO/TD-1007, edited by: Braconnot, P., Canada, 4-8 October 1999, 25-42, 2000.

K-1 model developers: K1 coupled GCM (MIROC) description, edited by: Hasumi, H. and Emori, S., 34 pp, available at: http://www.ccsr.u-tokyo.ac.jp/kyosei/hasumi/MIROC/ tech-repo.pdf, last access: 8 November 2011, 2001.

Kalnay, E., Kanamitsu, M., Kistler, R., Collins, W., Deaven, D., Gandin, L., Iredell, M., Saha, S., White, G., Woolen, J., Zhu, Y., Chelliah, M., Ebisuzaki, W., Higgins, W., Janowiak, J., Mo, K. C., Ropelewski, C., Wang, J., Leetmaa, A., Reynolds, R., Jenne, R., and Joseph, D.: The NCEP/NCAR 40-year reanalysis project, B. Am. Meteorol. Soc., 77, 437-471, 1996.

Kidson, J. W.: An automated procedure for the identification of synoptic types applied to the New Zealand region, Int. J. Climatol., 14, 711-721, 1994.

Kidson, J. W.: Relationship of New Zealand daily and monthly weather patterns to synoptic weather types, Int. J. Climatol., 14, 723-737, 1994.

Kidson, J. W.: The utility of surface and upper air data in synoptic climatological specification of surface climatic variables, Int. J. Climatol., 17, 399-413, 1997.

Kidson, J. W.: An analysis of New Zealand synoptic types and their use in defining weather regimes, Int. J. Climatol., 20, 299-316, 2000.

Lamy, F., Hebbeln D., Rohl, U., and Wefer, G.: Holocene rainfall variability in southern Chile: a marine record of latitudinal shifts of the Southern Westerlies, Earth Planet. Sci. Lett., 185, 369382, 2001.

Leathwick, J. R. and Whitehead, D.: Soil and atmospheric water deficits and the distribution of New Zealand's indigenous tree 
species, Funct. Ecol., 15, 233-242, 2001.

Legutke, S. and Voss, R.: The Hamburg atmosphere-ocean coupled model ECHO-G. Technical Report 18, German Climate Computer Center (DKRZ), available at: http://www.mad.zmaw. de/fileadmin/extern/documents/reports/ReportNo.18.pdf, last access: 8 November 2011, 1999.

Li, X., Rapson, G. L., and Flenley, J. R.: Holocene vegetational and climatic history, Sponge Swamp, Haast, south-western New Zealand, Quaternary Int., 184, 129-138, 2008.

Lorrey, A., Fowler, A. M., and Salinger, J.: Regional climate regime classification as a qualitative tool for interpreting multi-proxy palaeoclimate data spatial patterns: A New Zealand case study, Palaeogeogr. Palaeoclimatol., 253, 407-433, 2007.

Lorrey, A., Williams, P., Salinger, J., Martin, T., Palmer, J., Fowler, A., Zhao, J. X., and Neil, H.: Speleothem stable isotope records interpreted within a multi-proxy framework and implications for New Zealand palaeoclimate reconstruction, Quaternary Int., 187, 52-75, 2008.

Manson, B. R.: The life history of silver beech (Nothofagus menziesii), Proceedings of the New Zealand Ecological Society, 21, 27-31, 1974.

Martin, T. J. and Ogden, J.: The seed ecology of Ascarina Lucida: A rare New Zealand tree adapted to disturbance, New Zeal. J. B., 40, 397-404, 2002.

Martin, T. J. and Ogden, J.: Experimental studies on the drought, waterlogging, and frost tolerance of Ascarina Lucida Hook. f. (Chloranthaceae) seedlings, New Zeal. J. Ecol., 29, 53-59, 2005.

McGlone, M. S. and Bathgate, J. L.: Vegetation and climate history of the Longwood Range, South Island, New Zealand, New Zeal. J. B., 21, 293-315, 1983.

McGlone, M. S. and Moar, N. T.: The Ascarina decline and postglacial climatic change in New Zealand, New Zeal. J. B., 15, 485-489, 1977.

McGlone, M. S., Neall, V. E., and Clarkson, B. D.: The effect of recent volcanic events and climatic changes on the vegetation of Mt Egmont (Mt Taranaki), New Zealand, New Zeal. J. B., 26, 123-144, 1988.

McGlone, M. S., Salinger, M. J., and Moar, N. T.: Paleovegetation studies of New Zealand's climate since the Last Glacial Maximum, in: Global climates since the Last Glacial Maximum, edited by: Wright, Jr, H. E., Kutzbach, J. E., Webb III, T., Ruddiman, W. F., Street-Perrott, F. A., and Bartlein, P. J., University of Minnesota Press, Minneapolis, 294-317, 1993.

Mullan, A. B.: Southern Hemisphere sea-surface temperatures and their contemporary and lag association with New Zealand temperature and precipitation, Int. J. Climatol., 18, 817-840, 1998.

Neuner, G., Bannister, P., and Larcher, W.: Ice formation and foliar frost resistance in attached and excised shoots from seedlings and adult trees of Nothofagus menziesii, New Zeal. J. B., 35, 221227, 1997.

Newnham, R. M., Lowe, D. J., and Green, J. D.: Palynology, vegetation, and climate of the Waikato lowlands, North Island, New Zealand, since c. 18,000 years ago, J. Roy. Soc. New Zeal., 19, 127-150, 1989.

Ogden, J., Stewart, G. H., and Allen, R. B.: Ecology of New Zealand Nothofagus forests, Pages 25-82, in: The ecology and biogeography of Nothofagus forests, edited by: Veblen, T. T., Hill, R. S., and Read, J., Yale University Press, New Haven, Conneticut, USA.
Ohgaito, R. and Abe-Ouchi, A.: The role of ocean thermodynamics and dynamics in Asian summer monsoon changes during the Mid-Holocene, Clim. Dynam., 29, 39-50, 2007.

Phipps, S. J., Rotstayn, L. D., Gordon, H. B., Roberts, J. L., Hirst, A. C., and Budd, W. F.: The CSIRO Mk3L climate system model version 1.0 - Part 1: Description and evaluation, Geosci. Model Dev., 4, 483-509, doi:10.5194/gmd-4-483-2011, 2011.

Randall, D. A., Wood, R. A., Bony, S., Colman, R., Fichefet, T., Fyfe, J., Kattsov, V., Pitman, A., Shukla, J., Srinivasan, J., Stouffer, R. J., Sumi, A., and Taylor, K. E.: Climate Models and Their Evaluation, in: Climate Change 2007: The Physical Science Basis. Contribution of Working Group I to the Fourth Assessment Report of the Intergovernmental Panel on Climate Change, edited by: Solomon, S., Qin, D., Manning, M., Chen, Z., Marquis, M., Averyt, K. B., Tignor, M., and Miller, H. L.: Cambridge University Press, Cambridge, UK and New York, NY, USA, 2007.

Renssen, H., Driesschaert, E., Loutre, M. F., and Fichefet, T.: On the importance of initial conditions for simulations of the MidHolocene climate, Clim. Past, 2, 91-97, doi:10.5194/cp-2-912006, 2006.

Renwick, J. A.: Kidson's synoptic weather types and surface climate variability over New Zealand, Weather and Climate, 31, 3-23, 2011.

Roeckner E., Arpe, K, Bengtsson, L., Christoph, M., Claussen, M., Dümenil, L., Esch, M., Giorgetta, M., Schlese, U., and Schulzweida, U.: The atmospheric general circulation model ECHO-G4: model description and simulation of present-day climate, Technical Report. 218, Max Planck Institut für Meteorologie, 1996.

Rojas, M. and Moreno, P. I.: Atmospheric circulation changes and neoglacial conditions in the Southern Hemisphere mid-latitudes: insights from PMIP2 simulations at $6 \mathrm{kyr}$, Clim. Dynam., 31, 357-375, doi:10.1007/s00382-010-0866-3, 2011.

Rojas, M., Moreno, P., Kageyama, M., Crucifix, M., Hewitt, C., Abe-Ouchi, A., Ohgaito, R., Brady, E. C., and Hope, P.: The Southern Westerlies during the last glacial maximum in PMIP2 simulations, Clim. Dynam., 32, 525-548, 2009.

Salinger, M. J.: New Zealand climate I: Precipitation patterns, Mon. Weather Rev., 108, 1892-1904, 1980a.

Salinger, M. J.: New Zealand climate II: Temperature patterns, Mon. Weather Rev., 108, 1905-1912, 1980b.

Salinger, M. J. and Mullan, A.B.: New Zealand climate: Temperature and precipitation variations and their links with atmospheric circulation 1930-1994, Int. J. Climatol., 19, 1049-1071, 1999.

Schaefer, J. M., Denton, G. H., Kaplan, M., Putnam, A., Finkel, R. C., Barrell, D. J. A, Andersen, B. G., Schwartz, R., Mackintosh, A., Chinn, T., and Schulchter, C.: High-frequency Holocne glacier fluctuations in New Zealand differ from the northern signature, Science, 324, 622-625, 2009.

Singarayer, J. S. and Valdes, P. J.: High-latitude climate sensitivity to ice-sheet forcing over the last $120 \mathrm{kyr}$, Quaternary Sci. Rev., 29, 43-55, 2010.

Sturman, A. P., Trewinnard, A. C., and Gorman, P. A.: A study of atmospheric circulation over the South Island of New Zealand (1961-1980), Weather and Climate, 4, 53-62, 1984.

Sun, O. J. and Sweet, G. B.: Comparison of frost tolerance of Nothofagus solandri var. cliffortioides (Hook.f.) Poole and Nothofagus menziesii (Hook.f.) Oerst, New Zeal. J. B., 34, 273- 
278, 1996.

Tait, A., Henderson, R., Turner, R., and Zheng, Z.: Thin plate smoothing spline interpolation of daily rainfall for New Zealand using a climatological rainfall surface, Int. J. Climatol., 26, 2097-2115, 2006.

Vandergoes, M. J., Fitzsimmons, S. J., and Newnham, R. M.: Late glacial to Holocene vegetation and climate change in the eastern Takitimu Mountains, western Southland, New Zealand, J. Roy. Soc. New Zeal., 21, 53-66, 1997.

Wagner, S., Widmann, M., Jones, J. M., Haberzettl, T., Lücke, A., Mayr, C., Ohlendorf, C., Schäbitz, F., and Zolitschka, B.: Transient simulations, empirical reconstructions and forcing mechanisms for the Mid-Holocene hydrological climate in southern Patagonia, Clim. Dynam., 29, 333-355, 2007.
Wardle, R.: Using anticyclonicity to determine the position of the Southern Hemisphere westerlies, Geophys. Res. Lett., 30, 2200, doi:10.1029/2003GL018792, 2003.

Wolff, J., Maier-Reimer, E., and Legutke, S.: The Hamburg Primitive Equation Model HOPE, in: Technical Report 18, German Climate Computer Center (DKRZ). 